\title{
Guinea: Poverty Reduction Strategy Paper-Third Annual Progress Report
}

Poverty Reduction Strategy Papers (PRSPs) are prepared by member countries in broad consultation with stakeholders and development partners, including the staffs of the World Bank and the IMF. Updated every three years with annual progress reports, they describe the country's macroeconomic, structural, and social policies in support of growth and poverty reduction, as well as associated external financing needs and major sources of financing. This country document for Guinea, dated June 2006, is being made available on the IMF website by agreement with the member country as a service to users of the IMF website.

To assist the IMF in evaluating the publication policy, reader comments are invited and may be sent by e-mail to publicationpolicy@imf.org.

$$
\begin{gathered}
\text { Copies of this report are available to the public from } \\
\text { International Monetary Fund • Publication Services } \\
70019^{\text {th }} \text { Street, N.W. • Washington, D.C. } 20431 \\
\text { Telephone: (202) 623-7430 • Telefax: (202) 623-7201 } \\
\text { E-mail: publications@imf.org • Internet: http://www.imf.org }
\end{gathered}
$$

Price: $\$ 18.00$ a copy

\section{International Monetary Fund Washington, D.C.}





\section{REPUBLIC OF GUINEA}

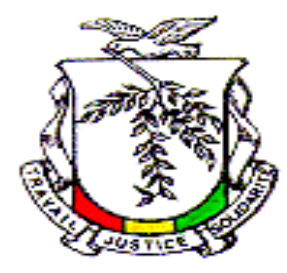

MINISTRY OF STATE FOR ECONOMIC DEVELOPMENT

MINISTRY OF ECONOMY AND FINANCE

PERMANENT SECRETARIAT OF THE PRS

THIRD PROGRESS REPORT ON THE POVERTY REDUCTION STRATEGY

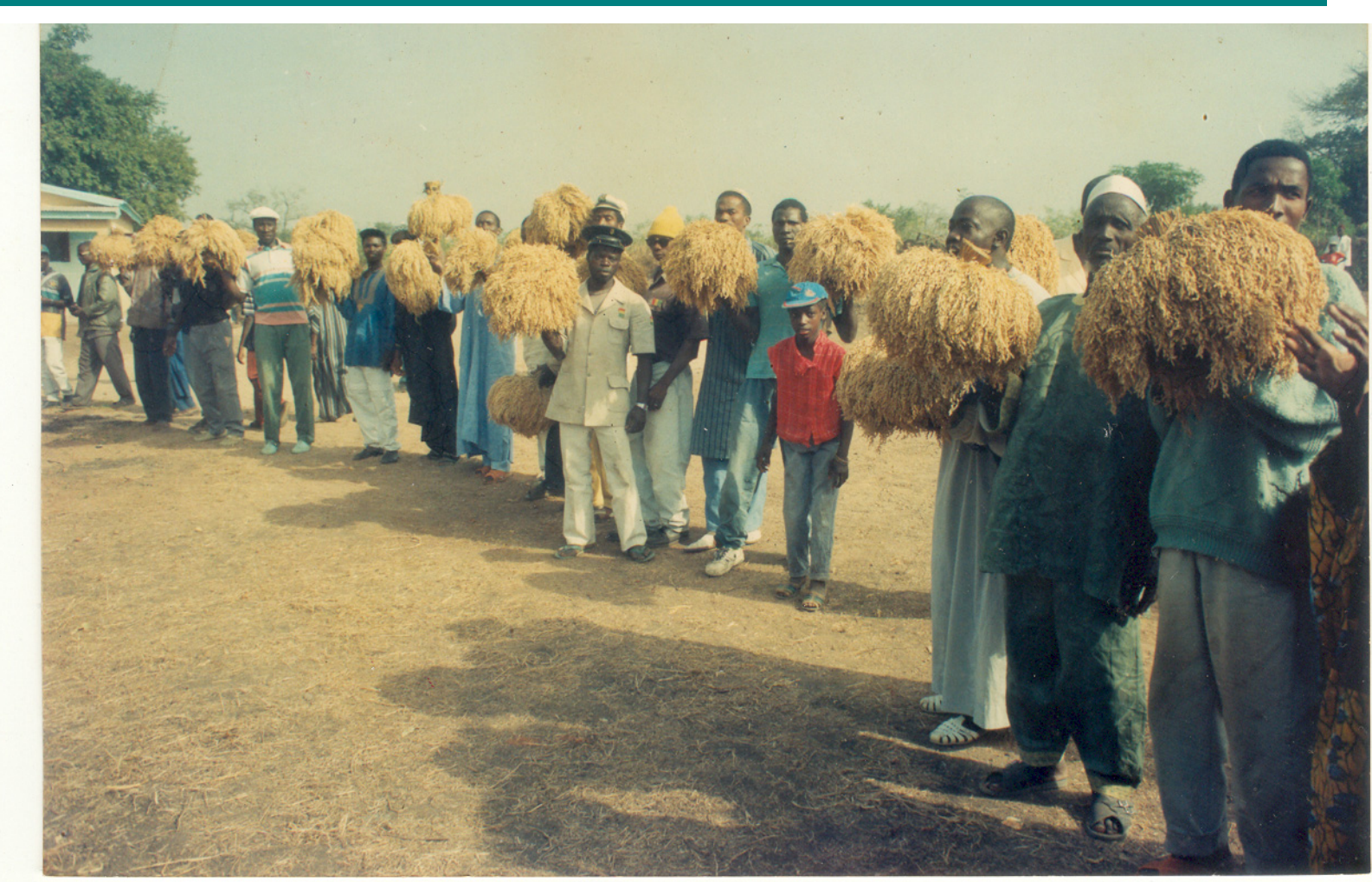

June 2006 


\section{TABLE OF CONTENTS}

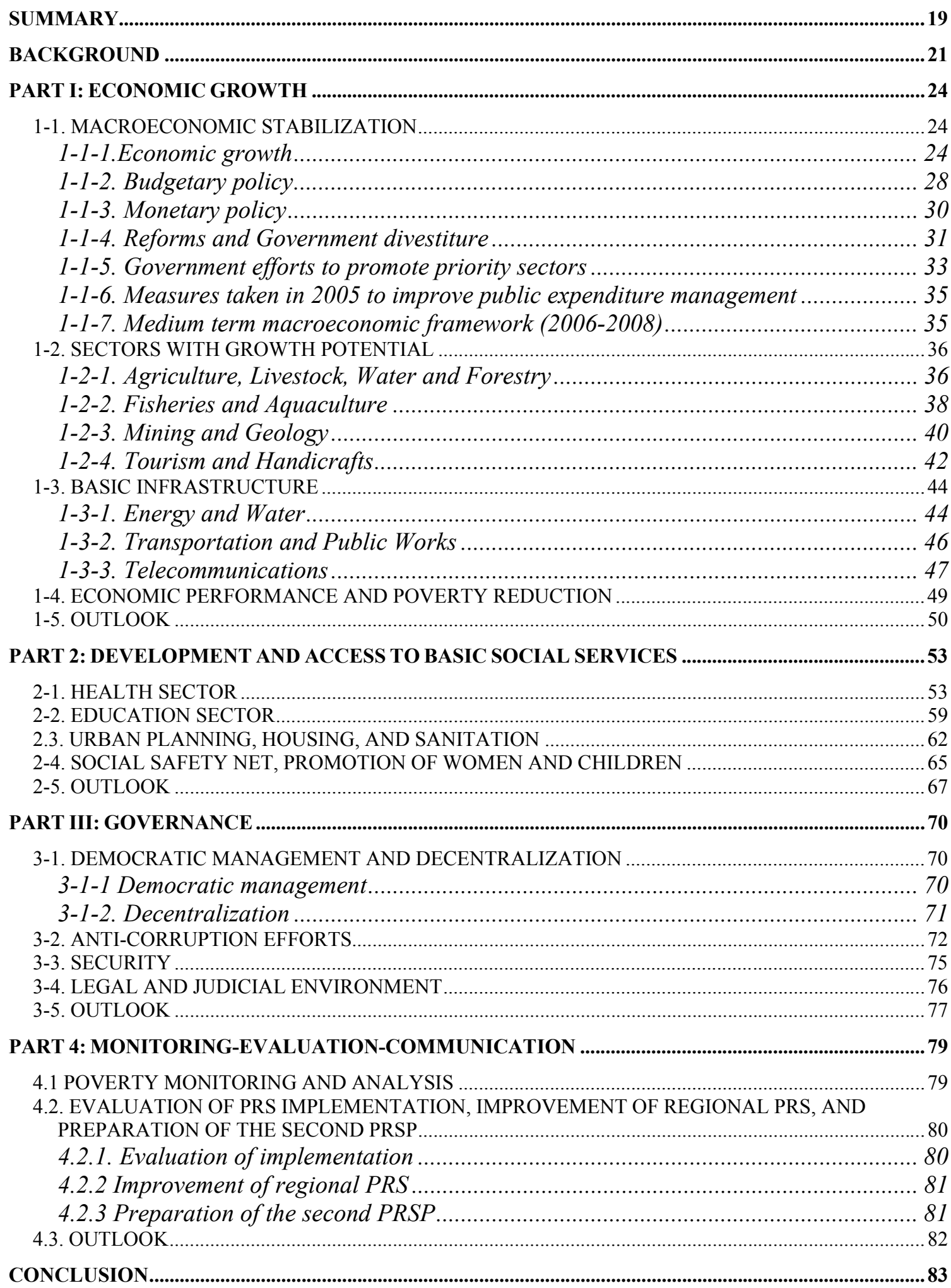




\section{LIST OF GRAPHS}

GRAPH 1: TREND IN REAL GDP/PER CAPITA GDP GROWTH, 2002-2005 (\%) ..........................................25

GRAPH 2: GROWTH RATE OF PRIMARY SECTOR, 2002-2005 (\%) ...........................................................26

GRAPH 3: GROWTH RATE IN THE SECONDARY SECTOR, 2002-2005 (\%) ..................................................2 27

GRAPH 4: GROWTH RATE IN TERTIARY SECTOR, 2002-2005 (\%) ..............................................................28

\section{LIST OF TABLES}

TABLE 1: TRENDS IN PUBLIC FINANCING, 2003-2005 (AS \% OF GDP) ........................................................29

TABLE 2: MONETARY AGGREGATES IN 2005 ……...........................................................................................30

TABLE 3: SALE OF ASSETS AND SHARES OF ENTERPRISES, 2005 ......................................................32

TABLE 4: INVESTMENT EXPENDITURES IN PRIORITY SECTORS, 2002-2005 (\%) ................................33

TABLE 5: AGRICULTURAL PRODUCTION TRENDS, 2003-2005 (000 METRIC TONS AND \%).............37

TABLE 6: FISHERIES AND AQUACULTURE, PROJECTION AND PERFORMANCE .................................39

TABLE 7: MINING AND GEOLOGY: PROJECTIONS AND PERFORMANCE ...........................................41

TABLE 8: RESULTS OF WORKS COMPLETED AS OF END 2005 ................................................................45

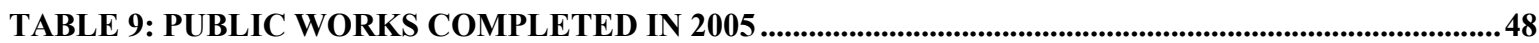

TABLE 10: TELECOMMUNICATIONS: WORKS COMPLETED, 2002-2005 ..............................................49

TABLE 11: PRIVATIZATION OBJECTIVES FOR 2006

TABLE 12: VACCINATION COVERAGE RATES BY ANTIGEN, 2002-2005.................................................56

TABLE 13: SEROPREVALENCE AND POVERTY RATES BY ADMINIOSTRATIVE REGION................58

TABLE 14: INDICATORS AND PERFORMANCE IN EDUCATION SECTOR...........................................60

TABLE 15: CURRENT GOVERNMENT EXPENDITURES FOR EDUCATION, 2002-2005 (GNF

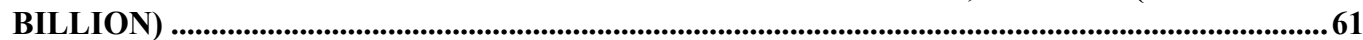

TABLE 16: INTRASECTORAL DISTRIBUTION OF THE EDUCATION BUDGET (GNF BILLION) .......62

TABLE 17: ACHIEVEMENTS IN THE URBAN PLANNING, HOUSING, AND SANITATION SECTOR. 64

TABLE 18: SUMMARY OF PRS IMPLEMENATAION RESULTS IN GUINEA .........................................85

TABLE 19: EXECUTION OF EXPENDITURES IN PRIORITY SECTORS ......................................................90

TABLE 20: PRS MONITORING/EVALUATION INDICATORS ..........................................................................91 


\section{Error! No table of contents entries found.ACRONYMS}

\begin{tabular}{|c|c|}
\hline AfDB & African Development Bank \\
\hline AFP & Acute flaccid paralysis (in poliomyelitis) \\
\hline AGEVAL & Association Guinéenne des Evaluateurs (Appraisers' Assoc.) \\
\hline AIP & Annual investment plan \\
\hline ANLC & $\begin{array}{l}\text { Agence Nationale de Lutte contre la Corruption et de moralisation } \\
\text { des activités économiques et financières (Anti-Corruption } \\
\text { Agency) }\end{array}$ \\
\hline AVCS & $\begin{array}{l}\text { Agents Vaccinateurs des Centres de Santé (Health Center } \\
\text { Vaccinators) }\end{array}$ \\
\hline BCG & Tuberculosis vaccine \\
\hline BCRG & $\begin{array}{l}\text { Banque Centrale de la République de Guinée (Central Bank of } \\
\text { Guinea) }\end{array}$ \\
\hline BG & Basse Guinée (Lower Guinea) \\
\hline BOT & Build Operate Transfer \\
\hline BTP & Bâtiments et Travaux Publics (Construction/Public Works sector) \\
\hline CAAF & Centre d'Appui à l'Autopromotion Féminine (Women's Center) \\
\hline CALP & Central Administration for Large Project \\
\hline CECOJE & $\begin{array}{l}\text { Centre d'Ecoute, de Conseils et d'Orientation pour les Jeunes } \\
\text { (Youth Counseling Center) }\end{array}$ \\
\hline CIT & Customs and Import Taxes \\
\hline CNLC & $\begin{array}{l}\text { Comité National de Lutte contre la Corruption (Anti-Corruption } \\
\text { Committee) }\end{array}$ \\
\hline $\mathrm{CNO}$ & Centre National d’Orthopédie (National Orthopedic Center) \\
\hline CPM & Comité de Passation des Marchés (Procurement Committee) \\
\hline $\mathrm{CPN}$ & Centre Préfectoral de Nutrition (Prefectural Nutrition Center) \\
\hline CRD & $\begin{array}{l}\text { Communauté Rurale de Développement (Rural Development } \\
\text { Community) }\end{array}$ \\
\hline CST & $\begin{array}{l}\text { Comité de Suivi des Travaux entièrement autonomes (Autonomous } \\
\text { Works Oversight Committee) }\end{array}$ \\
\hline CTA & Centre de Traitement Ambulatoire (Ambulatory Care Center) \\
\hline CVS & Counseling and Voluntary Screening \\
\hline DAF & $\begin{array}{l}\text { Division Administrative et Financière (Administrative and } \\
\text { Financial Division) }\end{array}$ \\
\hline DCE & $\begin{array}{l}\text { Direction Communale de l'Education (Communal Education } \\
\text { Directorate) }\end{array}$ \\
\hline DNP & Direction Nationale du Plan (National Planning Directorate) \\
\hline DNPF & $\begin{array}{l}\text { Direction Nationale de la Promotion Féminine (National } \\
\text { Directorate for the Advancement of Women) }\end{array}$ \\
\hline DPE & $\begin{array}{l}\text { Direction Préfectorale de l'Education (Prefectural Education } \\
\text { Directorate) }\end{array}$ \\
\hline DTCP & Diphtheria, Tetanus, Whooping Cough and Polio (vaccine) \\
\hline EFA & Education For All \\
\hline EFAP & Education for All Program \\
\hline
\end{tabular}




\begin{tabular}{|c|c|}
\hline EIBEP & $\begin{array}{l}\text { Enquête Intégrée de Base pour l'Evaluation de la Pauvreté } \\
\text { (Integrated Core Survey for Poverty Assessment) }\end{array}$ \\
\hline ENACOG & Enquête Nationale sur la Corruption et la Gouvernance en Guinée \\
\hline ESB & Enquête Situationnelle de Base (Baseline Status Survey) \\
\hline EU & European Union \\
\hline EVP & Expanded Vaccination Program \\
\hline FENAG & $\begin{array}{l}\text { Fédération Nationale des Artisans de Guinée (National Federation } \\
\text { of Artisans) }\end{array}$ \\
\hline FINEX & Financement Extérieur (external financing) \\
\hline GDP & Gross Domestic Product \\
\hline GER & Gross enrollment ratio \\
\hline GNF & Guinée Nouveau Franc (New Guinean Franc) \\
\hline GT & Groupe thématique (thematic group) \\
\hline $\mathrm{HG}$ & Haute Guinée (Upper Guinea) \\
\hline HIPC & Heavily indebted poor countries \\
\hline HIV/AIDS & $\begin{array}{l}\text { Human Immunodeficiency Virus/Acquired Immune Deficiency } \\
\text { Syndrome }\end{array}$ \\
\hline IDB & Islamic Development Bank \\
\hline IFT & Integrated Framework for Trade \\
\hline IMF & International Monetary Fund \\
\hline IHCCD & Integrated Health Care Coverage for Childhood Diseases \\
\hline LDP & Local development program \\
\hline LFR & Loi des Finances Rectificative (Supplemental Budget) \\
\hline MATD & $\begin{array}{l}\text { Ministere de l'Administration du Territoire et de la } \\
\text { Décentralisation (Ministry of Town/Regional Planning and } \\
\text { Decentralization) }\end{array}$ \\
\hline MDG & Millennium Development Goals \\
\hline MEF & Ministry of Economy and Finance \\
\hline MEPU / EC & $\begin{array}{l}\text { Ministère de l'Enseignement Pré-universitaire/Education Civique } \\
\text { (Ministry of Pre-University and Civic Education) }\end{array}$ \\
\hline MG & Moyenne Guinée (Middle Guinea) \\
\hline MP & Ministry of Planning \\
\hline MTEF & Medium Term Expenditure Framework \\
\hline MURIGA & $\begin{array}{l}\text { Mutuelles pour la prise en charge des Risques liés à la Grossesse } \\
\text { et à l'Accouchement (Health Mutual System for Obstetrical Care) }\end{array}$ \\
\hline NA & National Assembly \\
\hline NDB & National Development Budget \\
\hline NER & Net Enrollment Ratio \\
\hline NGO & Non-governmental organization \\
\hline NMP & National Malaria Program \\
\hline PACV & $\begin{array}{l}\text { Programme d'Appui aux Communautés Villageoises (Village } \\
\text { Community Support Program) }\end{array}$ \\
\hline PNLP & Programme national de lutte contre le paludisme \\
\hline PRCI & $\begin{array}{l}\text { Programme de Renforcement des Capacités Institutionnelles } \\
\text { (institutional capacity building program) }\end{array}$ \\
\hline
\end{tabular}




\begin{tabular}{|c|c|}
\hline PRS & Poverty Reduction Strategy \\
\hline PRSP & Poverty Reduction Strategy Paper \\
\hline PTAF & $\begin{array}{l}\text { Programme Triennal d'Alphabétisation des Femmes (three-year } \\
\text { women's literacy program) }\end{array}$ \\
\hline RPRS & Regional Poverty Reduction Strategy \\
\hline SME / SMI & Small and Medium Enterprises/Industries \\
\hline SSP & $\begin{array}{l}\text { Service Statistique et Planification de l'Education (Educational } \\
\text { statistics and planning service) }\end{array}$ \\
\hline STI & Sexually Transmitted Infection \\
\hline UNDP & United Nations Development Program \\
\hline VAA & Yellow Fever Vaccine \\
\hline VAR & Measles Vaccine \\
\hline $\mathrm{VAT}-2+$ & Tetanus vaccine, $2^{\text {nd }}$ dose \\
\hline VAMZ & West African Monetary Zone \\
\hline
\end{tabular}




\section{EXECUTIVE SUMMARY}

This report, the third in a series, reflects PRS implementation in 2005. It describes the status of PRSP objectives, assesses progress made relative to performance in 2004, and puts forth proposals for attaining the objectives set.

In 2005, the PRS was implemented in an overall context characterized by an obvious dearth of development funding. More specifically, the economic context continues to suffer from inadequate external financial assistance and from high inflation (29.7 percent) resulting from the steep depreciation of the Guinean franc. The worsening of inflation and the severe depreciation of the Guinean franc have contributed to the precipitous decline in household purchasing power, thereby rendering living conditions even more precarious.

In addition, the now chronic delivery problems affecting water and especially power are hampering the expansion of SME/SMI activity. Wealth- and job-creation options are thus being curtailed and thousands of people deprived of substantial amounts of income.

Even now, although peace has been restored to Sierra Leone and Liberia, it remains imperative to secure our borders with these countries, at an expense that continues to weigh heavily on the national budget. In terms of humanitarian issues, Guinea is still feeling the damaging effects of the conflict. Although many refugees have returned to their countries, the 63,264 other refugees still present on Guinean soil are taking a toll in economic, social, and environmental terms.

Despite all these contingencies, the Government has managed to put in place a staff-monitored program with the IMF, and the results of its implementation have been satisfactory overall.

Regarding economic growth, PRS implementation has been based upon the program agreed with the IMF. Implementation of the program measures has gradually stabilized the macroeconomic situation. Thus, real GDP growth reached 3.3 percent in 2005 compared to 2.7 percent in 2004, relative to a population growth rate of 3.1 percent. Average economic growth over the 2002-2005 period was 2.9 percent. 
With regard to monetary policy, despite the relative stability of exchange rates between the parallel and official markets, the level of foreign exchange reserves stood at 1.1 months of imports in 2005, compared to a goal of 6 months set forth in the PRSP. The lack of budgetary aid and the unsustainable weight of external debt service, the unification and liberalization of the foreign exchange market in March 2005, and the nonrepatriation of export revenues would presumably explain the weak performance.

According to the results of the poverty assessment survey (EIBEP) conducted in 2002/2003, the population living below the poverty threshold was estimated at 53.6 percent in 2005, compared to 50.1 percent in 2004 and 49.2 percent in 2002, i.e., a deterioration of 4.4 percent in four years. This worsening is due to poor macroeconomic performance characterized by a low rate of economic growth.

The priority sectors accounted for 58.6 percent of investment expenditures under the National Development Budget (NDB) in 2005, a decline relative to the 2004 figure of 73.0 percent. Although the share of the priority sectors in the NDB has decreased, however, it should be noted that the share of the social sectors, such as education and health, has increased. Education accounted for 5.8 percent of the NDB in 2004, and then for 13.5 percent in 2005 . The share of the health sector went from 1.7 percent in 2004 to 5.6 percent in 2005.

This drop in allocations to priority sectors in 2005 is believed to be attributable, among other things, to poor management of the MTEF units, the failure to monitor funding, and the low level of budgetary aid.

Progress in budgetary aid has occurred very recently. Indeed, the Government has instituted the 'program budget' approach to resource allocation. With this in mind, the Ministry of Economy and Finance held a training workshop in June 2005 to build staff capacities in the area of program budget concepts. It was planned that, upon completion of this workshop, six ministerial departments would be chosen to test the project.

This approach, which emphasizes program-based budgeting and threeyear resource allocation based on objectives and mandates, will make it possible to gear the government budget to priorities set out in the PRSP, and will probably also decrease extra-budgetary expenditures in the security and defense sectors. 
Over the medium term, the main macroeconomic objectives pursued by the Government will include:

- Average real GDP growth of 5.5 percent per annum;

- Reduction of inflation from its annual average of 24 percent in 2006 to 6 percent by 2008;

- An increase in the Central Bank's foreign exchange reserves from the equivalent of 1.5 months of imports in 2006 to 2.3 months by 2008;

- Maintenance of the budget deficit (excluding grants) at 0.3 percent of GDP in 2006; and

- A positive budget balance (excluding grants) from 2007 onwards.

In the area of agriculture, livestock, water, and forestry, production of food crops (e.g., rice, maize, fonio millet, cassava, and groundnuts) has increased substantially. From 900,000 metric tons in 2004, rice production reached 972,000 metric tons in 2005, an increase of 8 percent. Fonio production was 219,000 metric tons and that of groundnuts 183,000 metric tons in 2005, for increases of 10 percent and 9 percent, respectively, over 2004 levels.

In the fisheries sector, the most significant accomplishments were noted in scientific research and in terms of improved knowledge of the state of our fisheries resources. In addition, the fisheries sector has completed preparation of a strategic development plan for fisheries research, and has established a national plan for ray and shark conservation. Also noteworthy are the completion of a study aimed at identifying new fisheries, such as crabbing, and the creation of a Scientific Committee within the National Center for Fisheries Science at Boussoura (CNSHB).

In the mining and geology sector, the growth rate increased from 1.10 percent in 2004 to 3.6 percent in 2005. This increase is due to the Government's numerous promotional efforts to enhance mining administration, train human resources, and support megaprojects. The Government has signed the Extractive Industries Transparency Initiative (EITI).

Regarding tourism and handicrafts, the main activities carried out were of a normative nature, and included in particular the review and updating of implementing provisions of the Handicrafts Code at a workshop held in Mamou in April. These provisions relate to improved maintenance of the Artisans' Registry and Enterprise Registry and to the functioning of the handicrafts trade. 
Activities recorded in the energy sector included: continued on-site interventions in Conakry and in secondary cities; completion of works to install three thermal power plants at Kankan, N'Zérékoré and Faranah; preparation of a final version of the Master Plan for electrification; and development of an electrification project involving 24 localities. This document was presented to a national workshop organized in March 2006 by the Department of Energy. In the water subsector, most interventions are carried out by SNAPE. From 2002 to 2005, the number of boreholes developed annually by SNAPE declined from 749 (2002) to 252 (2005). The figure for 2005 represents 39 fewer water points in 2005 than in 2004. Well construction numbers have fallen each year (by 7 wells on average) since 2002.

In telecommunications, the main activities carried out in 2005 involved the expansion of the SOTELGUI telephone network. The number of cities served by the GSM network went from 21 to 22, out of a total of 33, for a service coverage rate of 67 percent. The city of Dabola is the most recent to be incorporated into SOTELGUI's GSM network. The two other operators, Intercel and Spacetel, serve only the city of Conakry. The granting of a fourth license to InvestCom should improve telephone service coverage in the country. The main challenge is that of the quality of the services provided by operators, which leaves much to be desired.

\section{Social sectors}

In the health sector, several activities planned in 2005 yielded positive results. In connection with efforts to combat diseases targeted under the expanded vaccination program (EVP), the rate of DTCP3 vaccination coverage improved, rising from 63 percent to 89 percent between 2004 and 2005.

In terms of coverage by prefecture, 30 out of 33 prefectures have a DTCP3 vaccination coverage rate exceeding 80 percent and the 8 others have a coverage rate below 80 percent. Rates of VAR and VAA antigen coverage have improved, going from 60 percent to 82 percent, and from 77 percent to 84 percent, respectively, between 2004 and 2005. In addition, the number of integrated health posts rose from 604 to 623, i.e., an increase of about 3 percent. The number of integrated health centers increased from 395 to 399 over the same period, an increase of 4 percentage points. 
The dynamism shown in public health was critical in reducing all categories of infant mortality. Infant, child, and infant/child mortality rates dropped from 98 per thousand to 91 per thousand, from 88 per thousand to 79 per thousand, and from 177 per thousand to 163 per thousand, respectively, between 1999 and 2005. Despite this decline, rates still fall short of the stated goal, namely, an infant mortality rate of 70 per thousand.

On the other hand, malnutrition among children under the age of five is still not under control, since 26 percent of children manifested growth deficiency in 2005, compared to 23 percent in 1999, and 35 percent of children are underweight, compared to 26 percent in 1999. If appropriate measures are not taken to boost awareness and to step up efforts to combat poor dietary habits, this situation could have a negative impact on mortality trends.

In terms of HIV/AIDS prevention, the Government's numerous efforts in the areas of information dissemination, screening, coverage of treatment costs of persons living with HIV (PLHIV), and strengthening of infrastructures should be noted.

In 2005, of 5,002 women tested, 1,550 were placed on antiretroviral (ARV) treatment, 1,295 of them free of charge. Seven thousand eight hundred $(7,800)$ AIDS orphans, including 1,078 girls, were taken into financed care. These measures are helping both to mitigate the suffering of PLHIV and reduce their financial expenses, thereby reducing poverty and extending the life expectancy of AIDS sufferers to some extent. The synergetic effect of these interventions has held the rate of HIV/AIDS seroprevalence below the 5 percent rate set forth in the PRSP. Prevalence rates are 1.5 percent nationally: 1.9 percent among women and 0.9 percent among men.

In the education sector, results indicate that the gross primary enrollment ratio (GPER) continues to improve: it stood at 79 percent in 2005 compared to 77 percent in 2004. The rate for girls also increased, reaching 73 percent in 2005 .

At this pace, it is highly likely that MDGs in the education sector will be reached by 2012. The girl/boy ratio at the primary level is improving, rising from 0.76 to 0.79 from 2004 to 2005. At the secondary level, this ratio ranges from 0.47 to 0.49 . 
School access rates are significant: 73.3 percent for the country overall. In urban areas, the rate is nearly 89 percent in Conakry and 87 percent in other cities of the interior. The ratio in rural areas is 67.4 percent.

Regarding efforts to fund education sector development in furtherance of the MDGs and Poverty Reduction Strategy Objectives (PRSO), the Government contribution in terms of current expenditures is larger than in other social sectors. Current government expenditures rose from GNF 671.76 billion in 2004 to GNF 1,221.49 billion in 2005, while those of the education sector went from GNF 165.46 billion to 197.92 billion. Although current expenditures in the education sector are increasing as a percentage of GDP, they only account for 1.7 percent of expenditures. This share is low compared to the average for Sub-Saharan Africa, which is about 4 percent. This indicates the extent of the additional effort required to meet the needs of the education sector.

In the area of social welfare and the promotion of women's and children's interests, results for 2005 were the following: (i) updating of national policy on the promotion of women and the training of officials of the National Directorate for Women's Affairs and its subsidiaries in management and public administration, as well as in management of development projects; (ii) training of male and female outreach workers of the women's centers (Centres d'Appui à l'Auto-promotion Féminine, CAAF) and "NAFA" Centers (for non-formal education) at Kaloum, Fria, Labé, and Lélouma in family life and birth control education, as well as provision of equipment to these centers; (iii) establishment of 19 Financial Service Associations (FSA) in the prefectures of Dabola, Dinguiraye, Faranah, Kankan, Kouroussa, Kérouané, and Mandiana. These Associations, through the placement of 101,793 shares, mobilized capital valued at GNF 101.8 million in real terms and obtained credit totaling GNF 331.4 million; (iv) positive assessment at Lorombo (Cisséla subprefecture) of the first round of reinsertions involving 97 residents of the Cité de Solidarité; and (v) examination by the Government, during April 2005, of the report on the actuarial evaluation of the National Social Security Fund (Caisse Nationale de Sécurité Sociale, CNSS) for purposes of enforcing measures concerning:

- Raising of floor and ceiling salary levels subject to withholding;

- Raising of the retirement age;

- Improving registration and coverage of contribution; 
- Reorganization of the financial relationship between the CNSS and the Government.

In the area of governance and capacity building, 2005 was dominated by (i) the creation, by decree, of a National Electoral Commission (Commission Electorale Nationale Autonome, CENA), the role of which is to monitor the election process and to ensure that the roles are adhere to, thereby furthering the Government's efforts to make these elections transparent and fair consultations; (ii) Finalization of the draft Code of Decentralized Collectivities, which merges 87 legislative and regulatory texts into a single document; (iii) Training of 48 officers at the Sérédou training center in administration, management of collectivities, and election management techniques; and; (iv) Preparation and promulgation of two laws regulating the activities of associations, groups, mutuals, and cooperatives.

The focus of the Government's anti-corruption efforts was mainly training and outreach to stakeholders on the devastating impact of corruption on the country's development.

In this connection, the anti-corruption agency (Agence nationale de lutte contre la corruption et de moralisation des activités économiques et financiers, ANLC) strove, despite its scant resources, to carry out its mandate conscientiously in 2005. It received and examined 16 complaints submitted by citizens. Two of these were resolved to the parties' satisfaction, four were referred to the relevant jurisdictions, and 10 require travel to the interior of the country.

In addition, the ANLC held reporting workshops in July and August 2005 in the administrative regions and in Conakry to discuss the results of the corruption and governance survey. It also carried out IEC activities, including the planned showing of a documentary film, cartoons, and the installation of billboards concerning corruption and governance. The only activity remaining is the Faranah workshop, which is scheduled for July 2006. These workshops have been the preferred venue for the dissemination of results. A report on all the regional workshops is now available and has been published. The ANLC participated in governancerelated activities organized by public agencies, institutions, and development partners. 
Regarding the Extractive Industries Transparency Initiative, the Government and the World Bank agreed to establish a steering committee on transparency in the extractive industries. The Steering Committee was thus created by Decree 2858/MMG/SGG2005, and its members were appointed and assigned the task of compiling available statistics (on the basis of commitment or disbursement data from audits), and publishing data on mining revenues.

\section{Outlook}

Accelerating economic growth will again be a central concern of the Government in the upcoming years. Efforts in 2006 will undoubtedly need to address the following objectives:

(i) Strengthening of governance and anti-corruption efforts, including the strengthening of the national anti-corruption agency, ANLC, and the promulgation of new laws to combat corruption and money-laundering;

(ii) Expansion of the government divestiture program;

(iii) Intensification of the structural reform program;

(iv) Consolidation and strengthening of macroeconomic policies in order to ensure sustained macroeconomic stability.

In the area of tourism and handicrafts, the goal will be to improve the institutional framework by preparing a Code of Tourism aimed at providing greater incentives to private enterprises investing in the sector; conduct studies for the creation of a Pilot Artisans' Center, crafts villages, and a bamboo center; enhance the technical and professional capacities of stakeholders in the sector; and strengthen partnerships for the construction of tourist encampments.

Regarding fisheries and aquaculture, efforts must focus, among other things, on: (i) finalization of the Letter of Development Policy on Fisheries and Aquaculture and continued reorganization of the Ministry; (ii) intensification of the surveillance effort and of efforts to combat illegal fishing; and (iii) an increase in the number of research programs from 2 to 3. 
In the power and water sector, policies will be needed to restore the financial viability of public utility companies, to strengthen the regulatory framework, and to establish a pricing policy in keeping with the sector's social welfare objectives.

In the telecommunications sector, measures include the negotiation of operating licenses for operators in accordance with the new regulatory framework, and the preparation of an action plan, to be adopted in December 2006, for establishing the independent regulatory agency provided for under the new telecommunications law.

In the mining sector, reforms will aim to increase transparency and to strengthen the legal framework applicable to private investors.

In the health sector, in accordance with guidelines set out by the National Development Program for Health (NDPH), interventions planned for 2006 include:

- Decentralization of health care coverage of HIV in all administrative regions, including ARV treatment activities, psychosocial services, information to promote behavioral change, prevention of mother-tochild transmission, and support to associations of persons living with HIV;

- Strengthening of efforts to combat malaria and tuberculosis through IEC activities financed by the Global Fund;

- Pilot experiments aimed first at establishing a subcontracting system between the administration and the private sector with a view to better integrating the latter into the overall supply of services, and then at fostering a sense of ownership of health centers on the part of Rural Development Communities;

- Finalization and validation of the new pharmaceutical policy to improve regulation in this sector and, among other things, combat the illegal market and promote the establishment of private pharmacies in the interior of the country;

- Preparation of a human resource development plan aimed at recruitment planning, career management, staff training and incentives to work in poor areas; and 
- Creation of a midwifery track at the paramedical professions institute (Institut de formation et de spécialisation des professions paramédicales) at Donka, and decentralization of training programs for candidates seeking the specialized certification (certificat d'études spécialisées) for regional hospitals, to encourage them to work in rural areas.

In the area of urban development and housing, interventions will occur within the implementation framework of the following programs:

- National Site and Housing Development Program (Programme National d'Aménagement et de Développement de l'Habitat, PNADH);

- National Town and Regional Planning Program (Programme National d'Aménagement du Territoire, PNAT);

- Integrated Koba Tatéma-Bamako Subregional Development Program (Programme d’Aménagement Sous-régional Intégré de Koba Tatéma - Bamako);

- The Urban Technical Support Program (Programme d'Appui Technique aux Villes);

- Integrated Development Program for Mining Regions of Guinea (Programme de Développement Intégré des Régions Minières de la Guinée), and the Technical Study and Development Program for the Koloma Plateau (Programme d'études techniques et de travaux d’aménagement du Plateau de Koloma).

Regarding the social safety net and the promotion of women's and children's interests, activities planned for 2006 essentially deal with:

- Review of sectoral polices of the Ministry of Social Welfare, including those related to the promotion of Women and Children;

- Monitoring of facilities utilization and of funds to support targeted population segments;

- Strengthening of coordination capacities of the Three-Year Women's Literacy Program;

- Implementation of results of the qualitative and quantitative study of Guinea's street children and child labor;

- Organization of a subregional meeting on children in trouble with the law;

- Finalization of the analysis on the situation of orphans and vulnerable children, followed by development of an action plan; and

- Efforts to combat begging by children. 
On the anti-corruption front, the minimum program defined by the ANLC includes the following activities:

- Establishment of anti-corruption focal points within ministerial departments;

- Reorganization of the ANLC to add some authority on governance issues to its mandate;

- Preparation of an anti-corruption law.

In the area of security, interventions will include:

- Improvement of the institutional framework;

- Recruitment and capacity building of police officers (315 additional officers to increase civil security staff);

- Enhancement of facilities and infrastructures at the police academy in Boffa;

- Construction of 10 urban police commissariats in Conakry;

- Renovation of the central commissariats in Conakry and Dubréka;

- Second phase of construction of the DGPN in Coléah. 


\section{SUMMARY}

The Poverty Reduction Strategy Paper (PRSP) was adopted by the Government in January 2002, and endorsed by the IMF and World Bank in July 2002. The PRSP constitutes a single framework for all interventions by stakeholders involved in the economic and social development process in Guinea.

The overall objective of the PRS is to reduce poverty significantly and sustainably by boosting incomes and improving the well-being of the population, and particularly of the most vulnerable. The specific mediumand long-term objectives of the PRSP are the following:

\section{Medium term (2002-2005):}

- Achieve average annual GDP growth of 5.2 percent in real terms between 2002 and 2005;

- Boost the average annual per capita GDP growth rate to 1.9 percent between 2002 and 2005.

\section{Long term (2010):}

- Reduce the incidence of monetary poverty at the national level from 62.6 percent in 1994/95 to 30 percent by 2010, and the incidence in rural areas from 82.1 percent to 38 percent over the same period;

- Increase the gross primary enrollment ratio from 56.7 percent in 1999/00 to 100 percent by 2012 and the GER for girls from 44.3 percent to 100 percent over the same period;

- Reduce the infant mortality rate from 98 per thousand in 1999 to 70 per thousand in 2005 and 50 per thousand by 2010;

- Increase the rate of access to safe water from 49 percent in 1999 to 80 percent in 2005 and 100 percent in 2010.

The strategy for achieving these goals is based on three main themes, namely:

- Acceleration of economic growth, with ample income-earning opportunities for the poor;

- Expansion of basic social services and of equitable access to them;

- Improved governance and strengthening of institutional and human capacities. 
The purpose of this report is to report on PRS implementation progress in 2005 and derive lessons in order to determine the outlook for 2006. The report is arranged in four (4) parts:

1) Results achieved in implementation of economic growth policies;

2) PRS implementation in the area of development and access to basic social services;

3) Improvement of governance and strengthening of institutional and human capacities;

4) Monitoring and evaluation of PRS implementation. 


\section{BACKGROUND}

Implementation of the Poverty Reduction Strategy (PRS) in 2005 took place within an overall context characterized by a scarcity of development financing.

Specifically, Guinea's economic environment continues to be characterized by a lack of external financial assistance and high inflation (29.7 percent year-on-year) due to the steep depreciation of the Guinean franc. The steady depreciation of the currency simply reflects a failure of monetary policy due in part to a failure to adhere to prudential rules and to an increase in the money supply, which reached a level of 17.1 percent of GDP, compared to an objective of 15.6 percent.

The worsening of inflation and sharp depreciation of the Guinean franc have contributed to the precipitous decline in household purchasing power, rendering living conditions even more precarious. The picture presented by trends in prices of staple goods, and particularly for rice (GNF 2,472/kilo in December 2005, a 37 percent increase over 2004) and potatoes (GNF 1,507/kilo in December 2005, a 33 percent increase over 2004), is not reassuring.

In addition, it should be noted that the now routine shortages in water and power delivery are having a negative impact on SME/SMI activities. Wealth- and job-creation opportunities are being compromised, and thousands of people are thus being deprived of incomes that could improve their living conditions.

Even now, although peace has returned to Sierra Leone and Liberia, the securing of our borders remains a necessity of which the cost weighs heavily on the national budget.

Regarding humanitarian issues, Guinea is still suffering from the harmful effects of wars that have ravaged these two brother countries. Despite the repatriation of hundreds of thousands of Sierra Leoneans and Liberians, the presence of over 63,264 other refuges (51,428 Liberians and 5,121 Sierra Leoneans) exacts a cost in terms of social, economic, and environmental equilibrium. The repatriation of 1,416 Guineans living illegally abroad and of 107,719 others from Côte d'Ivoire in the wake of that country's troubles, are spurring the Government to greater efforts to manage the consequences of this instability. 
On the political side, PRS implementation occurred in a context characterized by a strengthening of the democratic process through the creation of the National Electoral Commission (Commission Electorale Nationale Autonome, CENA) and the organization of municipal and community-level elections under the supervision of this Commission. All of the country's major political parties, including those without seats in the National Assembly, participated in these elections.

The purpose of the elections was to replace the governing bodies of the decentralized collectivities, i.e., the rural development communities (CRD), most of which have been in place for fifteen years. The results of these elections indicated that the opposition obtained only 7 of 38 municipalities (18 percent), and 62 out of 303 CRDs, or 20 percent. The credibility and transparency of these elections were an important pre-condition of improved donor partnerships, especially with the European Union. In addition, a law concerning liberalization of the airwaves was examined and adopted by the deputies in January 2005. To this end, a commission consisting of representatives of the public administration set about preparing specifications to be presented to those requesting frequency bands.

The international environment in which the PRS is being implemented is characterized by numerous features and events that have disrupted economic and social trends. In terms of liberalization and globalization, the economic environment is characterized by:

- Frequent fluctuations in commodity prices, including petroleum. This has a negative impact on economic performance and makes it difficult to reach objectives;

- The decline in bilateral and multilateral Public Aid for Development (PAD); and

- Increased international awareness of such pertinent issues as HIV/AIDS, good governance, poverty reduction, women's rights, and environmental protection, and the proliferation of economic integration initiatives.

Despite all of these contingences, the Government has managed to put in place a staff-monitored program with the IMF. Within this framework, public expenditures have been contained, overall, within limits set by the program. 
The good performance achieved in the mobilization of internal revenues is due to the increased price of export products, and especially for bauxite, the price of which went from USD 20.8 per metric ton in 2004 to USD 22.4 per metric ton in 2005, and to the substantial efforts made to implement structural measures. Non-mining income totaled GNF 1,249.4 billion, compared to a goal of GNF 1,086.9 billion, a gain of GNF 162.5 billion. This gain is largely due to exchange rate depreciation, since the rate was higher than forecast.

This third implementation report of the Poverty Reduction Strategy reflects this overall situation of the Guinean economy. 


\section{PART I: ECONOMIC GROWTH}

Steady improvement of the macroeconomic framework is a major challenge. It permits strong and sustainable economic growth that can help reduce poverty, provided that its benefits are broadly distributed among the poor. To achieve its poverty reduction goal, the Government has set itself a number of medium-term objectives:

- Average annual growth of 5.2 percent in real terms between 2002 and 2005;

- Reduction of the overall budget deficit (commitment-based, excluding grants) from 5.4 percent to 1.3 percent between 2002 and 2005;

- Reduction of average annual inflation from 7 percent in 2002 to 3.5 percent by 2005;

- Maintenance of the share of the budget deficit financed by the BCRG at less than 10 percent of the previous year's revenues.

To achieve these economic growth objectives, the strategy put in place by the Government is essentially based on four (4) themes:

- Macroeconomic stabilization;

- Development of basic infrastructure;

- Support to sectors with growth potential; and

- Sustainable management of natural resources and the environment.

\section{1-1. MACROECONOMIC STABILIZATION}

The Government negotiated and obtained from the IMF a staff-monitored program covering the period from April 2005 to March 2006, backed by economic recovery measures. As a result of these measures, the trends observed in Guinea's economy indicate an improvement of the macroeconomic framework.

PRS implementation results also reflect recovery measures taken in the area of macroeconomic stabilization.

\section{1-1-1.Economic growth}

In 2005, implementation of the PRS was based on the staff-monitored program agreed upon with the IMF and covering the April 2005 - March 2006 period. The quantitative objectives of this program include: 
1. Real GDP growth of 3 percent in 2005;

2. Targeting a year-on-year inflation rate of 28 percent in 2005;

3. Targeting of the GNF/USD exchange rate to 3,200;

4. Reduction of the current account deficit from 5.5 percent of GDP in 2004 to 3.8 percent in 2005;

5. Improvement of the overall balance, from a deficit of 2.5 percent of GDP in 2004 to a surplus of 0.1 percent of GDP in 2005;

6 . Increase in gross foreign exchange reserves from the equivalent of 0.8 months of imports to 1.3 months of imports during 2005;

7. Maintenance of the overall public financing deficit (cash basis) at 1 percent of GDP during the first half of 2005;

8. Holding monetary expansion at 32.1 percent by end 2005;

9. Reaching a primary surplus of 0.5 percent of GDP in 2005.

Effective implementation of the measures included in this program has gradually restored macroeconomic stability.

\section{Graph 1: Trend in real GDP/per capita GDP growth, 2002-2005 (\%)}

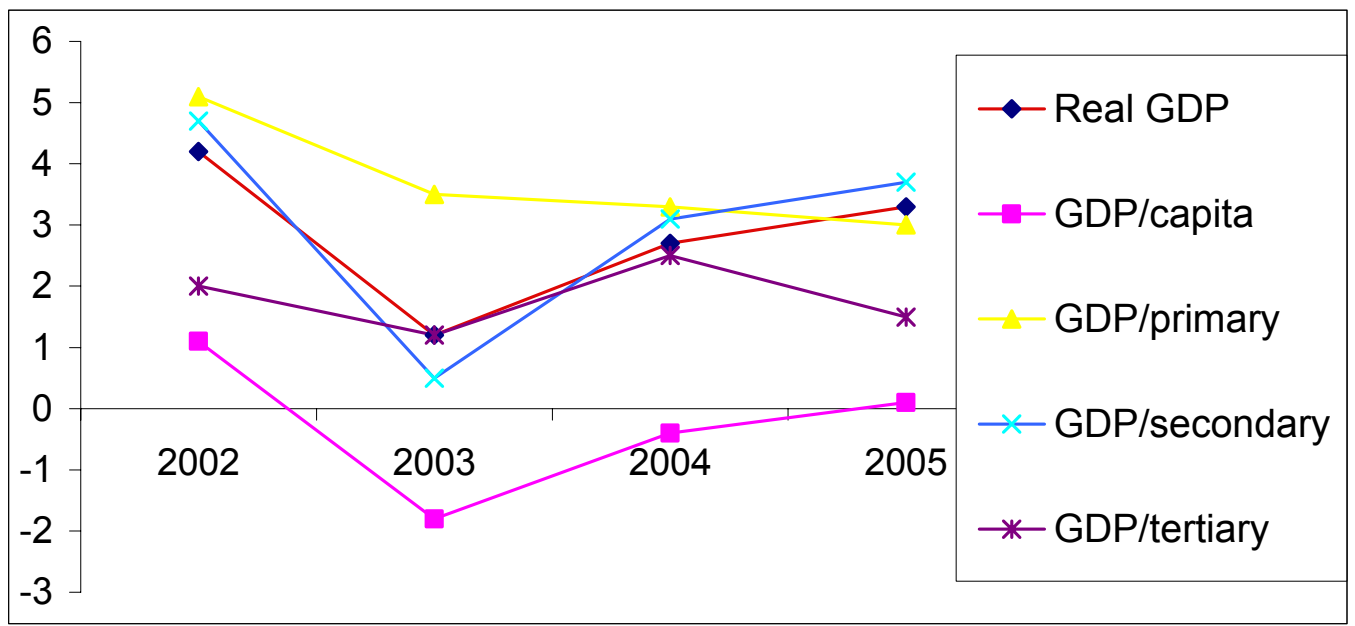

Source: MP/DNP: Macroeconomic Policy framework, November 2005

Indeed, the economic growth rate reached 3.3 percent in 2005, compared to 2.7 percent in 2004 , an increase of 0.6 percent. This improvement is a result of higher production levels in certain economic sectors, and particularly in the secondary sector. As the preceding graph indicates, the increase was reflected in an average real GDP growth rate of 2.9 percent per annum, although it falls below the average rate of 5.2 percent projected by the PRSP for the 2002-2005 period. While the rate stood at 4.2 percent in 2002, it dropped to about 1.2 percent in 2003, and then recovered slightly in 2004 (2.7 percent) before settling at 3.3 percent in 2005. 
Average per capita GDP growth per annum was -0.3 percent, i.e., well below the target of 1.9 percent set by the PRSP. The rate fell from 1.1 percent in 2002 to -1.8 percent in 2003, and then to -0.4 percent in 2004 , settling at 0.1 percent in 2005. This poor performance is a result of poor agricultural productivity, difficulties with delivery of power, water, telecommunications, and construction materials, and the absence of external funding, particularly under the HIPC Initiative.

On the other hand, all of the quantitative objectives of the staff-monitored program were achieved.

At the sectoral level, results in the area of economic growth are presented in Graphs 2, 3 and 4 of this report.

\section{i) Primary sector}

Graph 2: Growth rate of primary sector, 2002-2005 (\%)

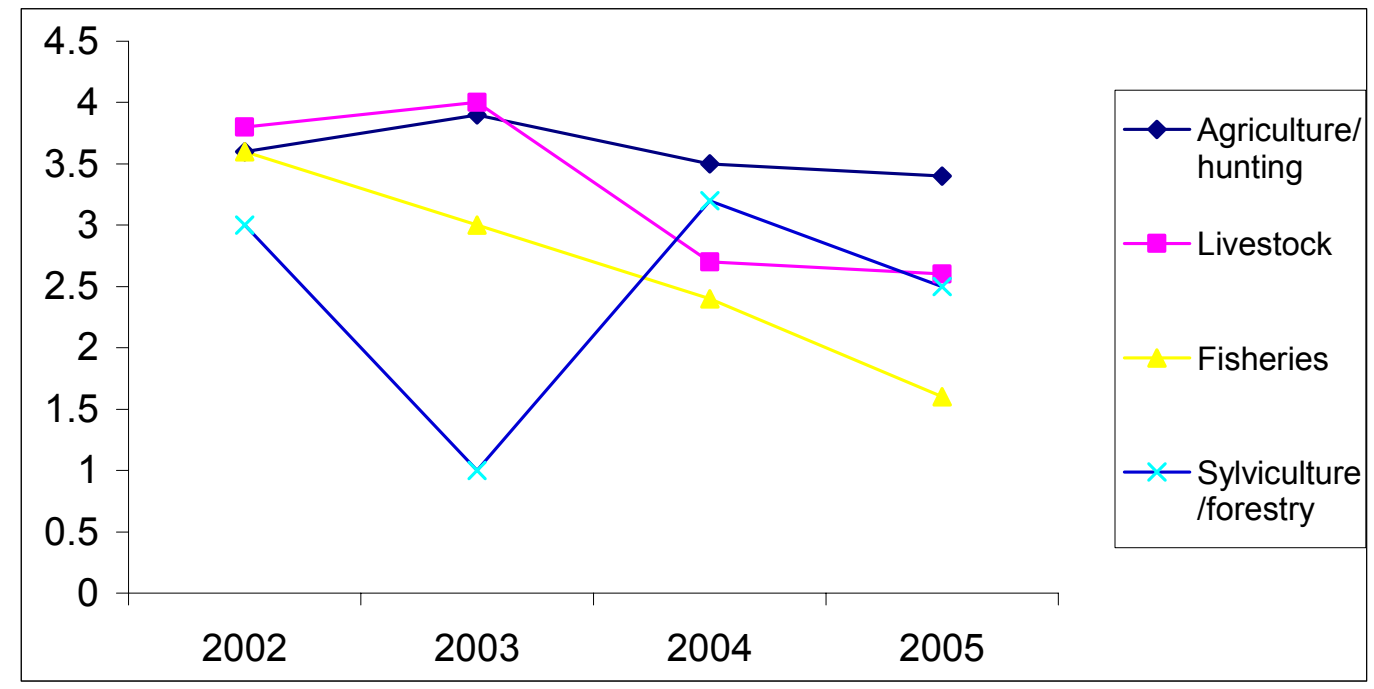

Source MP/DNP: Macroeconomic Policy, November 2005

The macroeconomic data indicates that GDP growth in the primary sector was 2.8 percent in 2005 compared to 3.3 percent in 2004, a drop of 0.5 percentage points. This decline in performance is due to problems encountered particularly in the subsectors of livestock (2.7 percent in 2004 to 2.6 percent in 2005), fisheries (2.4 percent to 1.6 percent), and sylviculture and forestry (3.2 percent to 2.5 percent). 


\section{ii) Secondary sector}

This sector as a whole experienced growth of 2.9 percent in 2004 and 4.1 percent in 2005. Apart from the manufacturing subsector, in which the growth rate fell from 3.0 percent in 2004 to 1.5 percent in 2005, growth rates in other subsectors improved slightly, as follows:

- Mining: 1.1 percent in 2004 to 3.6 percent in 2005;

- Water and electricity: 0.9 percent in 2004 to 1.0 percent in 2005;

- Construction and public works: stable growth of 6 percent in 2004 and 2005.

Despite the slight improvement noted in the water and power sector $(0.1$ percent), it should be mentioned that difficulties with water and electricity delivery are hampering Guinea's development. In fact, in a context characterized by rising oil prices, these problems are having a significant impact on SME/SMI development. In addition, widespread water and electricity shortages in outlying urban neighborhoods can aggravate serious criminal activity, thereby compromising law and order and the business climate.

Poverty reduction, therefore, requires improved access, on the part of households and enterprises, to water and electricity.

Graph 3: Growth rate in the secondary sector, 2002-2005 (\%)

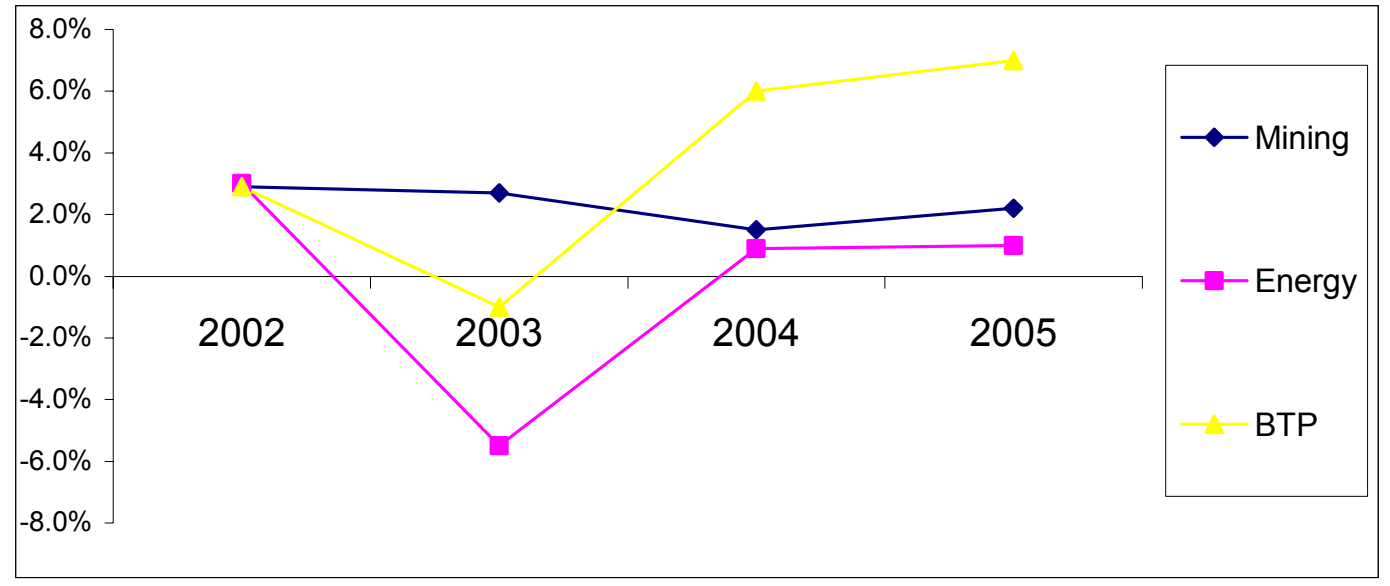

Source MP/DNP: Macroeconomic Policy framework, November 2005

\section{iii) Tertiary sector}

The tertiary sector, like the primary sector, slowed by 1.2 percentage points in 2005, with its growth rate falling from 2.6 percent in 2004 to 1.4 percent in 2005. Growth in the subsectors was as follows:

- Trade: from 2.8 percent in 2004 to 1.2 percent in 2005;

- Transportation: from 1.6 percent in 2004 to 1.3 percent in 2005; 
- Administration: from 2.5 percent in 2004 to 1.0 percent in 2005;

- Other services: from 2.5 percent in 2004 to 2.2 percent in 2005.

Graph 4: Growth rate in tertiary sector, 2002-2005 (\%)

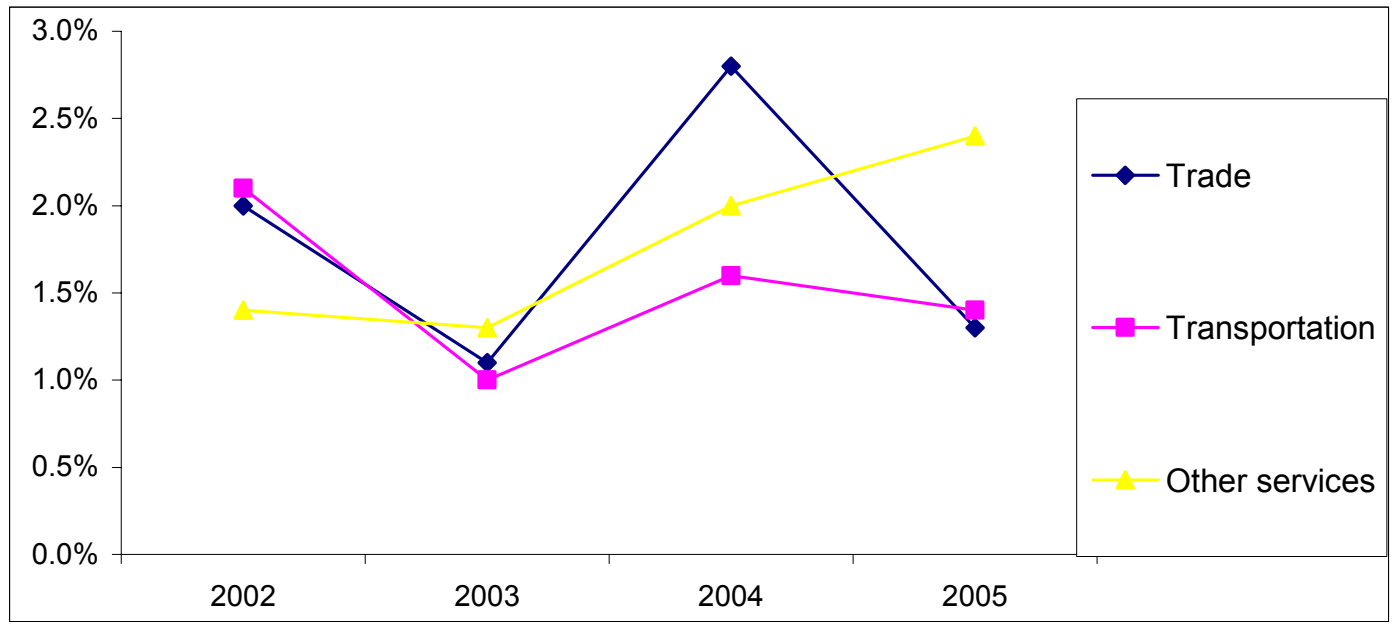

Source MP/DNP: Macroeconomic Policy framework, November 2005

It should be noted in conclusion that, in terms of financial resources, the secondary sector, and particularly the subsectors of construction/public works and mining, generated value-added totaling GNF 37 billion and 18 billion, respectively, over 2004.

\section{1-1-2. Budgetary policy}

Rigorous budget management, mainly in the area of internal revenue mobilization over the 2003-2005 period, reduced the budget deficit (grants excluded), which stood at -1.4 percent of GDP in 2005, compared to -7.9 percent and -5.9 percent for 2003 and 2004, respectively.

Table 1: Trends in public finances, 2003-2005 (as \% of GDP)

\begin{tabular}{|l|r|r|r|}
\hline \hline & 2003 & 2004 & 2005 \\
\hline REVENUE AND GRANTS & 13.7 & 11.4 & 14.4 \\
\hline Revenue & 10.4 & 10.5 & 13.2 \\
\hline Grants & 3.2 & 1.0 & 0.8 \\
of which HIPC & 0.9 & 0.5 & 0.2 \\
\hline TOTAL EXPENDITURES & 18.8 & 16.2 & 14.4 \\
\hline Current expenditures & 12.8 & 11.4 & 10.3 \\
\hline Investments & 5.4 & 5.0 & 4.2 \\
\hline
\end{tabular}




\begin{tabular}{|ll|r|r|r|}
\hline \multicolumn{2}{|l|}{ Debt service } & 3.4 & 5.4 & 3.4 \\
\hline $\begin{array}{l}\text { Overall fiscal balance (excl. } \\
\text { grants) }\end{array}$ & -7.9 & -5.9 & -1.4 \\
\hline \hline
\end{tabular}

Source: MP/DNP: Data from Macroeconomic Policy framework (MP) and TOFE $(M E F / D N B)$

This performance is attributable to: the increase in non-mining revenues resulting from strict enforcement of the structural measures put in place within the tax and customs administrations; the new customs tariff (based on WAEMU's Common External Tariff (CET)) entailing some new merchandize categories that differ somewhat from those of WAEMU ${ }^{1}$; and improved procedures for public expenditure execution. The CET has two interrelated objectives:

- Subregional economic integration by means of a customs union, to meet the challenges of development and globalization;

- Creation, within the ECOWAS zone, of an integrated economic bloc aimed at taking advantage of opportunities available under the Economic Partnership Agreement (EPA). These customs measures made a significant contribution to the Government's revenue mobilization, which is a sine qua non condition of macroeconomic stabilization and improvement of the business climate, especially where international trade is concerned.

Thus, Government revenues represented 13.1 percent of GDP, an increase of 2.6 percentage points over 2004. Grants, on the other hand, fell from 1.0 percent of GDP in 2004 to 0.8 percent of GDP in 2005. Funds mobilized under the HIPC Initiative, as a percentage of GDP, fell over the same period from 0.5 percent to 0.2 percent.

Public expenditures defined under the staff-monitored program were executed in 2005 to a level of 10.2 percent of GDP for current expenditures, and to a level of 5.1 percent of GDP for investment expenditures.

\footnotetext{
${ }^{1}$ For example, Guinea's CET allows duty-free entry of agricultural inputs and insecticides, while WAEMU's CET imposes duties of 5 percent and 15 percent, respectively, on these products.
} 


\section{1-1-3. Monetary policy}

Despite relatively stable exchange rates between the parallel and official markets, foreign exchange reserves equaled 1.1 months of imports in 2005, compared to the PRSP-defined goal of 6 months. This poor performance is due to a lack of budgetary aid, an unsustainable debt service burden, the unification and liberalization of the foreign exchange market in 2005, and the low level of national production.

Table 2: Monetary aggregates in 2005

\begin{tabular}{|l|l|l|l|}
\hline \hline & 2005 forecast & 2005 performance & Discrepancy \\
\hline Reserve money & GNF 959.6 billion & GNF 954.3 billion & GNF -5.3 billion \\
\hline $\begin{array}{l}\text { Foreign assets of } \\
\text { BCRG }\end{array}$ & USD 3.2 million & USD 5.1 million & USD + 2.9 million \\
\hline Broad money & GNF 1,855.7 billion & GNF 2,036.8 billion & GNF 181.1 billion \\
\hline $\begin{array}{l}\text { Credit to private sector } \\
\text { GNF } 617.3 \text { billion }\end{array}$ & GNF 699.6 billion & GNF 82.3 billion \\
\hline $\begin{array}{l}\text { Foreign assest of } \\
\text { commercial banks }\end{array}$ & $G N F 173.1$ billion & $G N F 277.5$ billion & GNF 104.4 billion \\
\hline \hline
\end{tabular}

Source: Ministry of Economy and Finance/Minister's speech to the National Assembly.

The low level of foreign exchange reserves, contributing to an increased money supply that reached 17.1 percent of GDP compared to an initial goal of 15.6 percent, was largely responsible for:

- The steep depreciation of the Guinean franc relative to the main foreign currencies. At the official average rate, the dollar was traded at GNF 3,646.59 in December 2005 compared to 2,466.67 in December 2004, i.e., a depreciation of 47.8 percent. Depreciation relative to the Euro amounted to 45.4 percent between 2004 and 2005, from GNF 3,099.44:1 to GNF 4,505.79:1;

- Increased lending to the private sector-GNF 82.3 billion over 2004-and a greater-than-expected increase in external assets of commercial banks, which totaled GNF 104.4 billion for 2005;

- A year-on-year inflation rate of 29.7 percent in 2005, compared to 27.6 percent in 2004. 
This inflation, which has reached worrisome levels, is responsible for the substantial decline in consumers' purchasing power and is aggravating the level and extent of poverty.

According to the 2002/2003 EIBEP survey, an estimated 53.6 percent of the population was living below the poverty threshold in 2005, compared to 50.1 percent in 2004 and 49.2 percent in 2002, a deterioration of 4.4 percent over four years. This worsening is due to poor macroeconomic performance characterized by low economic growth. According to a June 2005 World Bank report, the average growth discrepancy (2.3 percent) observed over the 2002-2005 period could, with a poverty/growth elasticity rate of -1.19 percent, increase poverty by 2.74 percent. $^{2}$ Since population growth (3.1 percent) is outstripping average economic growth, the phenomenon of poverty can only become worse.

\section{1-1-4. Reforms and Government divestiture}

Government disengagement from industrial and commercial activities is aimed at promoting development of the private sector, so that it can help boost economic growth and job creation.

The sale of assets and shares of enterprise capital that are owned by the Government in proportions ranging from 10 percent to 100 percent will be carried out gradually, based not only on the transferable nature of the enterprises' assets, but also on their strategic importance to the economic life of the nation.

The privatization process continued with the completion of activities unfinished in 2004, e.g., the sale of Diverma, the printing company Société Imprimerie Patrice Lumumba (SIPL), and movie theaters (the Palace in Conakry, the "km 36" in Coyah and one in Pita).

Regarding the aforementioned SIPL, the sale of its real estate assets brought the Government GNF 1.3 billion.

The 2005 activity program of the Privatization Unit included the sale of assets and shares of enterprises, as set out in the following table:

Table 3: Sale of assets and shares of enterprises, 2005.

\begin{tabular}{|l|c|c|c|c|c|}
\hline \hline Enterprise & Sector & Govt. & Share to be & $\begin{array}{c}\text { Remaining } \\
\text { share }\end{array}$ & Encashed value \\
\hline
\end{tabular}

${ }^{2}$ The 2.74 result is calculated by multiplying 1.19 by $2.3 \%$ (average growth discrepancy noted over the 2002-2005 period.) 


\begin{tabular}{|c|c|c|c|c|c|}
\hline & & share \% & $\begin{array}{c}\text { transferred } \\
\%\end{array}$ & $\%$ & $\begin{array}{c}\text { or } \\
\text { Remarks }\end{array}$ \\
\hline$B I C I G U I$ & Banking & 38 & 23 & 15 & GNF 13 billion \\
\hline$\overline{B P M G}$ & Banking & 41,66 & 21,66 & 20 & $\begin{array}{l}\text { Negotiations with the } \\
\text { Moroccan party have } \\
\text { reduced the share to be } \\
\text { transferred by Government } \\
\text { to } 21.66 \text { percent instead of } \\
26 \text { percent. }\end{array}$ \\
\hline$U G A R$ & Insurance & 18 & 8 & 10 & $\begin{array}{l}\text { Reconciliation of past } \\
\text { operations prior to sale of } \\
\text { shares. }\end{array}$ \\
\hline$S O M C A G$ & Petroleum & 34 & 20 & 10 & Sale not carried out. \\
\hline SOGUIRUSSE & Manufacturing & 15 & 15 & 0 & $\begin{array}{l}\text { Sale did not occur due to } \\
\text { legal liquidation of the } \\
\text { company. }\end{array}$ \\
\hline SOPRAG & Manufacturing & 10 & 10 & 0 & $\begin{array}{l}\text { Company has been inactive } \\
\text { for a long time. Instead of } \\
\text { sale of the Government's } 10 \\
\text { percent share, liquidation is } \\
\text { envisaged. }\end{array}$ \\
\hline SOPROCHIM & Manufacturing & 33 & 33 & 0 & $\begin{array}{l}\text { Resumption of operation of } \\
\text { the company, which has been } \\
\text { in technical stoppage, prior } \\
\text { to sale of shares. }\end{array}$ \\
\hline
\end{tabular}

Source: Ministry of Economy and Finance/ Privatization Unit, 2005

In addition to the sale of the above-mentioned enterprise shares, the sale of assets of other companies, including SIPECO, brought the Government GNF 257.3 million.

In total, out of a revenue forecast of GNF 14.6 billion budgeted for 2005, i.e., 0.12 percent of GDP, the Privatization Unit was able, with the help of outside firms, to mobilize GNF 14.2 billion, for a realization rate of about 97 percent.

In the social area, and with the help of the World Bank through the social fund established under CAS IV, benefit and retirement contributions were paid for 1,782 dismissed workers (both living and deceased) who had been working for Air Guinée, Apilec, Sogetrag, Diverma, OCR, Société d'Imprimerie Patrice Lumumba, Sakoba, ONACIG, and ONCFG. This Government divestiture encourages not only the emergence of a private sector and the balancing of the national budget, but also anti-poverty efforts, to the extent that payments to dismissed workers protect them from economic insecurity. 


\section{1-1-5. Government efforts to promote priority sectors}

Analysis of the 2005 Appropriation Law indicates that the Government made substantial efforts to adhere to PRSP objectives in priority sectors, although some problems persist.

The following table shows resources allocated to priority sectors between 2002 and 2005.

Table 4: Investment expenditures in priority sectors, 2002-2005 (\%)

\begin{tabular}{|l|c|c|c|c|}
\hline \hline Sectors & 2002 & 2003 & 2004 & 2005 \\
\hline Agriculture, Forestry and Livestock & 25.6 & 24.7 & 20.0 & 20.4 \\
\hline Fisheries and Aquaculture & 1.2 & 2.3 & 1.8 & 3.5 \\
\hline Public works & 3.1 & 6.8 & 17.0 & 9.9 \\
\hline Urban development and Housing & 2.3 & 4.2 & 25.3 & 4.5 \\
\hline Public heath & 4.5 & 3.4 & 1.7 & 5.6 \\
\hline Education & 12.6 & 6.6 & 5.8 & 13.5 \\
\hline Social welfare & 1.2 & 1.0 & 1.5 & 1.5 \\
\hline Total & 50.5 & 49.1 & 73.0 & 58.6 \\
\hline \hline
\end{tabular}

Source: Macroeconomic Policy framework, March and November 2005

This table indicates that the share of investment expenditures accounted for by the priority sectors in the NDB was 58.6 percent in 2005, a decrease relative to the 2004 level of 73 percent. However, although the share of the priority sectors in the NDB has declined, that of the social sectors, such as Education and Health, has increased. From a level of 5.8 percent in 2004, the education sector accounted for 13.5 percent of the NDB in 2005. The share of the health sector increased from 1.7 percent in 2004 to 5.6 percent in 2005. 
This decrease in allocations to priority sectors in 2005 is partly due to the difficulties that the Guinean economy has encountered over the past few years as a result of the poor management of the MTEF Units, weak monitoring, and the drastic decline in budgetary aid. However, it should be emphasized that progress could be made in the management of MTEFs. In 2005, the Government introduced a program budget approach to resource allocation. In this connection, a training workshop was held in June 2005 by the Ministry of Economy and Finance to strengthen human resource capacities in terms of program budget concepts. Upon completion of this workshop, it was agreed that six ministerial departments would be chosen to test the project.

This approach, which emphasizes program-based budgeting and

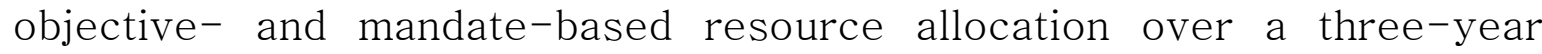
period, will better synchronize the Government budget with the priorities set forth in the PRSP, and will probably reduce extra-budgetary expenditures for the security and defense sectors.

In addition, the prospect of a program supported by the Poverty Reduction and Growth Facility (PRGF), and the resultant possibility to attain the HIPC Completion Point and the application of the program budget approach to resource allocation in priority sectors such as pre-university education, health, basic infrastructure, and village hydraulics, is expected to boost resource levels in the priority sectors.

In conclusion, with regard to macroeconomic stabilization, it can be stated that the results described above were obtained through emergency measures taken by the Government to improve the economic situation, and the monitoring of the program by the IMF.

Indeed, throughout 2005 the Government adhered resolutely to restrictive budgetary and monetary policies, and initiated the unification and liberalization of the foreign exchange market. It also pledged to create an environment more conducive to private sector development, particularly in terms of the transparency of the mining sector, improved governance in the area of public finance, banking oversight, and anti-corruption efforts. In addition, plans were adopted to enhance water and power distribution service and to privatize public assets. 


\section{1-1-6. Measures taken in 2005 to improve public expenditure management}

In order to improve public expenditure management, the Government has taken the following steps:

- Establishment of a strict budget accompanied by a restrictive monetary policy;

- Further reform in the public enterprise sector: water, power, and telecommunications sectors, in which technical and managerial weaknesses continue to be major constraints for the national economy;

- Improved governance and intensified anti-corruption efforts through implementation of structural measures involving the management of public expenditures, administration of justice, and emphasis on the moral dimensions of economic and financial activities;

- Strengthening of the institutional and human capacities of entities responsible for oversight and audits; and

- Development of the economic and social infrastructures needed to improve the business climate, a sine qua non condition for the emergence of a dynamic private sector.

\section{1-1-7. Medium term macroeconomic framework (2006-2008)}

In the coming years, the Government's primary macroeconomic objectives will be the following:

- Average annual GDP growth rate, in real terms, of 5.5 percent;

- Reduction of inflation from the annual average of 24 percent in 2006 to 6 percent in 2008;

- Increase in the foreign exchange reserves of the Central Bank from the equivalent of 1.5 months of imports in 2006 to 2.3 months by 2008;

- Limiting of the budget deficit (excluding grants) to 0.3 percent of GDP in 2006, and realization of a positive overall budget balance, grants excluded, from 2007 onward;

- Increasing the tax ratio from 13.8 percent in 2006 to 14.8 percent in 2008 and limiting total expenditures relative to GDP to around 14.5 percent during 2007;

- Limiting expansion of the money supply to restrain inflationary pressures. 


\section{1-2. SECTORS WITH GROWTH POTENTIAL}

\section{1-2-1. Agriculture, Livestock, Water and Forestry}

In the area of agriculture, livestock, water, and forestry, objectives include: improvement of rural living conditions; food security through increased agricultural productivity; professionalization of smallholders; and improved access for rural stakeholders to production factors and marketing circuits.

To achieve these objectives, the PRS is based on implementation of the Letter of Development Policy for Agriculture (LPDA1), which includes among its targets:

- Increased food crop production, greater agricultural competitiveness, and higher incomes in rural areas;

- Access for export crops to the subregional and international market;

- Rational management of natural resources to ensure sustainable performance in the rural sector.

In 2005, production increases, as detailed in the following table, were remarkable in some production streams. Food crop production (rice, maize, fonio, cassava, and groundnuts) increased significantly. Rice production rose from 900,000 metric tons in 2004 to 972,000 metric tons in 2005, i.e., an increase of 8 percent. Fonio production totaled 219,000 metric tons in 2005 and that of groundnuts 183,000 metric tons, for increases of 10 percent and 9 percent, respectively, over 2004.

These production gains were essentially obtained through expansion of cropped areas and higher yields resulting from the use of improved seed, intensified technology transfer, and some initial efforts at agricultural mechanization. Table 5 illustrates this trend.

Table 5: Agricultural production trends, 2003-2005 ('000 metric tons and \%)

\begin{tabular}{|l|r|r|r|r|r|}
\hline \hline & 2003 & \multicolumn{2}{|c|}{2004} & \multicolumn{2}{|c|}{2005} \\
\hline Rice & 845 & 900 & $7 \%$ & 972 & $8 \%$ \\
\hline Maize & 389 & 423 & $9 \%$ & 465 & $10 \%$ \\
\hline Fonio & 188 & 199 & $6 \%$ & 219 & $10 \%$ \\
\hline Unshelled groundnuts & 157 & 168 & $7 \%$ & 183 & $9 \%$ \\
\hline \hline
\end{tabular}

Source: Ministry of Agriculture, Livestock and Forestry 
Increased rice production made it possible to reduce imports, which fell from 333,236 metric tons in 2004 to 282,298 metric tons in 2005. However, Guinea is still heavily dependent upon these imports, which offset 28 percent of the food supply deficit overall, and 25 percent of the rice deficit.

This situation of dependency vis-à-vis external food supplies, along with the low rate of agricultural GDP growth (3.3 percent in 2005 compared to an annual average of 10 percent forecast in the PRSP) is a factor aggravating poverty, to the extent that over 70 percent of the population is concentrated in rural and engaged primarily in agriculture.

The agricultural sector contributes about 25.2 percent to national GDP formation. This contribution is still modest in view of the country's enormous agricultural potential.

It should be emphasized that agricultural exports could accelerate the sector's growth; this would be critical for overall economic growth and poverty reduction provided that the indispensable infrastructural investments, agricultural extension, and research are carried out with significant participation by the private sector, as recommended under the Integrated Framework for Trade (IFT). The goal is, among other things, to streamline the currently inefficient institutional framework, focusing it on the priority tasks of supporting enterprises, encouraging foreign investment, promoting exports, facilitating the circulation and outflow of agricultural products, and reducing administrative red tape.

Despite its relatively modest contribution to the economy, the agricultural sector is experiencing great difficulty with production and marketing, including:

- Problems transporting the harvest to urban centers;

- Poor promotion of products;

- Lack of selected seed;

- Low level of foreign investment in the sector and lack of crucial infrastructures;

- Irregular rainfall;

- Low productivity of local animal breeds/varieties in the livestock subsector;

- Poor fodder quality for livestock during the dry season;

- Lack of competitiveness of production, and difficulty in gaining access to international markets. 


\section{1-2-2. Fisheries and Aquaculture}

The general objectives assigned to this sector are: (i) development of coastal and inland fishing villages; (ii) development of sustainable rural fish farming in Middle Guinea and Forest Guinea; (iii) ensuring the sustainability of ocean and freshwater fisheries; and (vi) development of a national fishing industry adhering to international quality standards.

The specific objectives relate, among other things, to food security, poverty reduction, and increasing per capita fish consumption from 13 kilograms per year to 17 kilograms per year by 2010 .

In 2005, the most significant results were noted in scientific research and improvement of the state of knowledge of our ocean fisheries resources. Two research campaigns were conducted and resulted in:

- An assessment of demersal fish stocks;

- Observation of cetaceans in support of Guinea's position within the International Whaling Commission. This observation campaign, in which eight African countries participated in addition to the substantial cooperation of Japan, yielded observations in our waters of 1,567 individuals and the identification of 5 different species of cetacean.

In addition, the fisheries sector completed preparation of a strategic plan for development of fisheries research, and of a national plan for ray and shark conservation.

Other noteworthy accomplishments included the completion of a study aimed at identifying new fisheries, such as crabbing, and the creation of a Scientific Committee within the National Fisheries Science Center at Boussoura (CNSHB).

Table 6: Fisheries and aquaculture, projections and performance

\begin{tabular}{|l|l|l|}
\hline \hline Objectives/PRSP indicators & $\begin{array}{l}\text { Performance 2002-2003- } \\
2004\end{array}$ & Performance 2005 \\
\hline $\begin{array}{l}\text { Six (6) fisheries resource } \\
\text { evaluation campaigns, 2002 } \\
\text { through 2004 }\end{array}$ & One (1) campaign completed & \\
\hline $\begin{array}{l}\text { Train 1,500 farmers in fish } \\
\text { farming, and in water } \\
\text { collection/management }\end{array}$ & $\begin{array}{l}\text { Training and installation of } \\
\text { fish farmers and 34 } \\
\text { facilitators }\end{array}$ & $\begin{array}{l}\text { Training of 533 fish farmers operating } \\
482 \text { ponds for production of about 35 } \\
\text { metric tons/year. }\end{array}$ \\
\hline Provide 35 villages with & Start of work on developing & \\
\hline \hline
\end{tabular}




\begin{tabular}{|c|c|c|}
\hline $\begin{array}{l}\text { production infrastructures } \\
\text { by } 2004\end{array}$ & $\begin{array}{l}\text { fishing villages in Upper } \\
\text { Guinea }\end{array}$ & \\
\hline $\begin{array}{l}\text { Increase number of ponds } \\
\text { in production to } 460 \\
\text { between } 2002 \text { and } 2004\end{array}$ & Developing of 250 ponds & $\begin{array}{l}124 \text { ponds under construction - surface } \\
\text { area of } 25.68 \text { hectares }\end{array}$ \\
\hline $\begin{array}{l}\text { Increase the number of } \\
\text { credit beneficiaries to } 350\end{array}$ & $\begin{array}{l}\text { Establishment of credit for } \\
\text { artisanal fishermen (USD } \\
112,500 \text { ) }\end{array}$ & $\begin{array}{l}\text { Establishment of fund of USD 500,000, } \\
39 \text { million for women }\end{array}$ \\
\hline $\begin{array}{l}\text { Build } 3 \text { central fish markets } \\
\text { in large cities }\end{array}$ & $\begin{array}{l}\text { Completion of construction } \\
\text { Work on Kenyen fish market } \\
\text { Provision of } 3 \text { depots for } \\
\text { fresh fish in Conakry to the } \\
\text { National Union of Women Fish } \\
\text { Wholesalers } \\
\text { Provision of } 2 \text { fish markets to } \\
\text { the women fish wholesalers of } \\
\text { Kankan and Kouroussa }\end{array}$ & $\begin{array}{l}\text { Commencement of preparatory work on } \\
\text { construction of Siguiri and Mandiana } \\
\text { markets, through 'identification of } \\
\text { relevant sites. }\end{array}$ \\
\hline
\end{tabular}

Source: Speech delivered to National Assembly by Minister of Fisheries and Aquaculture

In the area of coastal surveillance, 341 ocean surveillance missions were conducted, resulting in the boarding of eighteen (18) vessels committing fishing infractions. This reduced the incidence of illegal fishing in deep waters.

The artisanal fishing and fish farming project completed construction of the Taborya wharf and established a fund of USD 500,000 for microcredit activities aimed at increasing the production of artisanal fisheries.

This fund made it possible to allocate GNF 39 million to women who engage in fish smoking operations and GNF 238.10 million to fishermen for the purchase of nets and motors. In connection with outreach to fishing communities, the UK-financed Sustainable Fishing Livelihoods Project (Projet Moyens d'Existence Durable dans la Pêche, PMED) provided several training modules to fishing communities to enhance their capacities in the area of coastal fisheries development.

The sector's contribution to improved food security has been compromised by constraints associated with rising oil prices, which have had a negative influence on the market price of fish. It should also be noted that in 2005 only 61,000 metric tons of frozen fish, 40,000 metric tons of fresh fish, and 8,000 metric tons of river-caught fish were landed. These quantities are well below the requirements of the population. 
Regarding inland fisheries, support involves training and installation of fish farmers. A total of 179 fish farmers, of whom 103 are already producing and 76 in the process of setting up, are receiving this support in 24 villages of Forest Guinea. In addition, 90 new candidates have been identified; 52 have had their prospective sites examined. These fish farmers are operating 101 open dams and 28 closed dams, with which production is occurring on a total surface area of 33.24 hectares, and 124 ponds under construction for a total surface area of 25.68 hectares.

The sector is encountering numerous obstacles to the attainment of its objectives, including: (i) inadequate equipment for fisheries surveillance; (ii) inadequate facilities for the reception, processing and storage of fisheries products; (iii) lack of suitable credit arrangements; (iv) weakness of infrastructures in industrial fishing, resulting in difficulty in boosting value-added in the sector; and (v) scarcity of funding, which is the main obstacle to development of the sector.

These difficulties have helped depress the sector's GDP growth rate, which fell from 2.4 percent in 2004 to 1.6 percent in 2005, i.e., a loss of 0.8 percentage points.

In terms of income, the objectives set for 2005 were fully achieved. The forecast revenues of GNF 21 billion were earned and deposited in the public treasury. This bottom line is the gratifying result of recovery measures carried out in 2005.

In sum, it should be noted that fisheries development could add value to the economy and make a great contribution to poverty reduction if the aforementioned constraints could be removed. Since over 80 percent of the poor are living in rural areas in the interior of the country or on the coast, any investment in the rural economy can have a major impact on poverty by creating jobs and increasing incomes.

\section{1-2-3. Mining and Geology}

The objective in the mining sector is to accelerate economic growth by exploiting the country's mining potential.

In 2005, the mining and geology sector increased its growth rate from $1.1 \%$ percent in 2004 to $3.6 \%$ in 2005 . This is the result of numerous promotional interventions on the part of the Government in support of mining administration, training of human resources, and support for megaprojects. 
Table 7: Mining and Geology: Projections and performance

\begin{tabular}{|c|c|c|c|}
\hline $\begin{array}{l}\text { Objectives/PRSP } \\
\text { indicators }\end{array}$ & \begin{tabular}{|l|} 
Performance \\
$2002-2003$
\end{tabular} & $\begin{array}{l}\text { Performance } \\
2004\end{array}$ & $\begin{array}{l}\text { Performance } \\
2005\end{array}$ \\
\hline $\begin{array}{l}\text { Annual growth rate (\%) of } \\
\text { the sector }{ }^{3}\end{array}$ & 2.7\% (en 2003) & $1.1 \%$ & $3.6 \%$ \\
\hline $\begin{array}{l}\text { Number of titles issued } \\
\text { per year }\end{array}$ & $\begin{array}{l}65 \text { mining titles, of } \\
\text { which } 50 \\
\text { prospecting } \\
\text { permits and } 15 \\
\text { mining } \\
\text { reconnaissance } \\
\text { permits }\end{array}$ & $\begin{array}{l}81 \text { mining titles, } \\
\text { of which } 73 \\
\text { prospecting } \\
\text { permits; } 2 \\
\text { concession } \\
\text { permits and } 6 \\
\text { mining } \\
\text { reconnaissance } \\
\text { permits }\end{array}$ & $\begin{array}{l}248 \text { prospecting } \\
\text { permits }\end{array}$ \\
\hline $\begin{array}{l}\text { Rate of processing of raw } \\
\text { materials intor semi- } \\
\text { finished or finished } \\
\text { products }\end{array}$ & & $4.4 \%$ & n.d. \\
\hline $\begin{array}{l}\text { Contribution to } \\
\text { community development }\end{array}$ & $\begin{array}{ll}\text { USD } & 1,840,000 \\
(2003) & \\
\end{array}$ & USD $1,546,800$ & n.d. \\
\hline
\end{tabular}

Source: Ministry of Mining and Geology

For purposes of exploiting our mining potential, 602 national operators and 475 foreigners have contacted the Mining Promotion Center (Centre de Promotion et de Développement Minier, CPDM) to carry out prospecting and resource valorization activities, particularly involving bauxite, iron, gold, diamonds, etc. The Government has joined the Extract Industries Transparency Initiative (EITI).

In this connection, the Government pledged to prepare two reports on payments and revenues in the mining sector. The first report, covering unaudited revenue figures, will be published in June 2006, while the second, covering audited income figures, is due in September 2006. At the same time, 248 prospecting and/or operating permits have been issued, all categories of mining operators combined, thereby bringing the number of permits to 81 for 2004 and 248 for 2005, i.e., an increase of over 310 percent. 
This demonstrates the Government's willingness to make mining a highgrowth sector that can create jobs and wealth and bring about a significant and sustainable reduction in poverty.

Within the framework of mining development, other large mining projects have been implemented. These include: (i) the Sangarédi Aluminum Plant Project, for which the amendment to the Global Alumina Agreement was signed and ratified; (ii) the Kamsar Aluminum Plant Project, for which the basic agreement has been signed with the partners of ALCOA/ALCAN; (iii) the Integrated Complex at Dian-Dian, etc.

Over the medium term, the mining sector will therefore be the actual motor of growth, since the new installations registered in 2005, and the expansion of those already existing, and particularly the integration of the bauxite/alumina/aluminum sector will contribute greater value-added to the national economy. Implementation of these megaprojects could provide an opportunity for power sector development and vice-versa. Indeed, the processing of alumina and the smelting of aluminum require abundant, reliable, and cheap energy.

In addition, implementation of megaprojects could generate substantial revenues for the Government as well as for rural communities, through the creation of nearly 22,000 permanent jobs and over 50,000 indirect jobs.

\section{1-2-4. Tourism and Handicrafts}

The objective is to accelerate the development of handicrafts through the creation of productive jobs, given their contribution to economic growth, job promotion, and mobilization of foreign currency.

Regarding tourism, the objectives for 2005 were the following:

- Production of regulatory texts on game-hunting tourism and the terms under which professional tourist guides may practice their profession;

- Production of a geographic atlas on tourism in Guinea;

- Partnerships with Tetarkys and Red International for the construction of village-based tourist encampments, particularly in Labé and Mali;

- Studies of the organization of tourism activities in the bay of Sangaréah and of the Dominyah tourism development project;

- Participation in training workshops, conventions, fairs, and expositions on tourism. 
Regarding handicrafts, the main activities carried out in 2005 were of a normative nature. These included the examination and updating of enforcing legislation of the Handicrafts Code at a workshop held in Mamou in April. These texts relate to the improvement of the maintenance of the Artisans' Registry and Business Registry and of the functioning of the handicrafts sector. Likewise, a number of terms of reference were drawn up for feasibility studies concerning "Pilot Artisans" interventions/projects/programs, the national census of artisans, the creation of handicrafts villages in Conakry and in the chief towns of administrative regions, child labor in the handicrafts industry, and handicrafts practiced by women in Guinea.

In addition, Phase 1 of the feasibility study, involving the diagnostic of the handicrafts sector and the definition of strategic options for the creation of the Pilot Artisans' Center in Conakry, is in progress. The draft report on the technical and architectural studies and the economic and financial analysis of the preliminary designs have been submitted for examination to the main stakeholders involved, including in particular the National Federation of Guinean Artisans.

The main constraints in the sector are:

- The scarcity and very high cost of production factors, i.e., water and electricity;

- Inadequate promotion abroad of Guinea as a tourism destination, along with scant attendance at commercial events (e.g., fairs, expositions, etc.);

- The high and uncompetitive cost of air travel to Guinea, and the total absence of charter flights.

Investments planned d by the Government to improve the accessibility and viability of tourism sites have also not been realized due to the country's financial constraints.

Most sites are still difficult to reach and in an undeveloped state. This has stymied national and foreign private operators and reduced their inclination to invest in the sector. 


\section{1-3. BASIC INFRASTRUCTURE}

\section{1-3-1. Energy and Water}

The objective in the energy sector is to improve the framework for economic development and the population's living conditions, by ensuring affordable access to energy.

In order to achieve the objectives set for this sector, reforms involving private operators need to be initiated.

In 2005, activities noted in the energy sector included: continuation of onsite interventions in Conakry and in secondary cities; completion of work required for connections to 3 thermal plants at Kankan, N’Zérékoré and Faranah; final preparation of a Master Plan for Electrification; and negotiation of financing arrangements for an electrification project involving 24 localities. This document was presented by the Minister of Energy to a national workshop held in March 2006.

In the electricity subsector, the entry into production of new mining areas should serve as an incentive to improve the quality of the electrical network and electric power supply. Indeed, the Ministry of Mining and Geology has just begun a broad campaign to promote and exploit resources.

Regarding the water subsector, the aim is to improve living conditions and the competitiveness of the economy by ensuring an adequate supply of good quality and affordable water. In this subsector, interventions are carried out essentially by SNAPE, which set itself the goal of carrying out the following projects in 2005:

- 949 positive boreholes;

- 16 simplified solar-powered water supply systems;

- 43 large-bore wells;

- 2,675 latrines;

- Rehabilitation of 8 solar-powered water supply systems with HIPC financing. 
Table 8: Results of works completed as of end 2005

\begin{tabular}{|c|c|c|c|c|c|}
\hline \multirow[b]{2}{*}{ Year } & \multirow{2}{*}{$\begin{array}{l}\text { Cumulative } \\
\text { objective }\end{array}$} & \multicolumn{4}{|c|}{ Annual completions } \\
\hline & & Boreholes & Wells & Total & Cumulative total \\
\hline 2002 & 12,600 & 741 & 8 & 749 & 11,613 \\
\hline 2003 & 13,400 & 646 & 12 & 658 & 12,271 \\
\hline 2004 & 14,200 & 283 & 8 & 291 & 12,562 \\
\hline 2005 & 15,000 & 252 & 0 & 252 & 12,814 \\
\hline
\end{tabular}

Source: SNAPE management/ Annual Activity Report, 2005.

The preceding table shows that activities completed did not meet the objectives set for 2005. It emphasizes the country's deficit in terms of hydraulic infrastructure coverage.

In terms of works completed from 2002 to 2005, the number of water points developed annually by SNAPE fell from 749 in 2002 to 252 in 2005. Relative to 2004, 39 fewer water points were developed in 2005. Well construction (averaging 7 wells) has declined each year since 2002.

SNAPE's cumulative objective was to produce 15,000 water points in 2005. The table above, however, shows an implementation rate of 82 percent, or 12,840 water points. The number of water points developed was 252, compared to the objective for 2005.

Along with borehole construction, SNAPE has conducted surveys to determine which villages meet the conditions for receiving a borehole. It has also initiated sanitation education campaigns concerning water point maintenance and hygienic practices to be observed in transporting, storing, and using water.

To the extent that these new infrastructures are in addition to those that existed previously, it seems reasonable to suppose that significant progress has been made in terms of access to safe water. Indeed, according to the 2002/2003 EIBEP, the rate of access to safe water stood at 64.3 percent in 2002 , compared to 51.5 percent in 1994/95, although there is a disparity between urban and rural areas (53 percent and 85.6 percent, respectively in 2002). 
Although real progress has been made in safe water access at the national level, it is regrettable that water supply conditions have deteriorated considerably in Conakry, with the result that no connection can be drawn to the PRSP indicators.

In sum, the Government's quantitative objectives set forth in the PRSP for hydraulics and electricity have not been fulfilled. In addition, if urgent measures are not taken, the attainment of MDGs in this sector will be compromised.

The main problems to be resolved are the following: i) financial viability of the subsectors, which requires considerable improvement in commercial returns (especially through vigorous anti-corruption efforts) as well as more rational management of resources; ii) development and sustainability of the concept of paying for public utilities; iii) strengthening of production and distribution capacities to meet the needs of the population, including in rural areas.

This cannot occur without a good partnership with the other institutions involved in water and power management. Thus, to achieve the objective of access to safe water, the priority areas for cooperation should be: (i) rehabilitation and expansion of the distribution network and improvement of management in the sector; and (ii) strengthening of production capacities at all levels, in large urban centers (water supply networks) and rural areas (boreholes and improved wells).

\section{1-3-2. Transportation and Public Works}

The overall objective of the transportation and public works sector is to enhance the mobility of people, goods, and services.

To this end, the Government is striving to define a strategy to reenergize urban transportation; this strategy aims to make the assets of the former transportation company Société Générale des Transports de Guinée (SOGETRAG) available to private investors wishing to develop urban and inter-city transportation. Preparation of a strategy to rehabilitate railroad transportation is also planned.

Activities carried out in 2005 are summarized in the following table. 
Table 9: Public works completed in 2005

\begin{tabular}{|c|c|c|}
\hline Objectives/PRSP indicators & Performance in 2004 & Performance in 2005 \\
\hline $\begin{array}{l}\text { Rehabilitation of } 1,000 \\
\text { kilometers of rural roads (2002- } \\
\text { 2004) }\end{array}$ & 689 kilometers rehabilitated & \\
\hline $\begin{array}{l}\text { Maintenance of } 5,750 \text { kilometers } \\
\text { of rural roads, including 1,250 } \\
\text { kilometers using labor-intensive } \\
\text { methods (2002-2003) }\end{array}$ & & $\begin{array}{l}770 \text { kilometers of } \\
\text { roads maintained }\end{array}$ \\
\hline $\begin{array}{l}\text { Construction of } 1,600 \text { linear } \\
\text { meters (Im) of crossing } \\
\text { structures (2002-2004) }\end{array}$ & $320 \mathrm{~lm}$ on the Fatala - Boffa road & \\
\hline $\begin{array}{l}\text { Periodic maintenance of } 3,950 \\
\text { kilometers of dirt roads ( } 2002- \\
\text { 2003) }\end{array}$ & $\begin{array}{l}689 \text { kilometers maintained } \\
\text { nationwide } \\
\text { Completion of maintenance work } \\
\text { on Doumbafè-Faranah and } \\
\text { Sankarani-Mandiana ferries }\end{array}$ & \\
\hline $\begin{array}{l}\text { Paving of } 1,169 \text { kilometers of } \\
\text { roads (2002-2007) }\end{array}$ & $\begin{array}{l}\text { - } 302 \text { kilometers paved, Kankan- } \\
\text { Kourémalé }\end{array}$ & \\
\hline $\begin{array}{l}\text { Within each administrative } \\
\text { capital: earthworks, sewer } \\
\text { installation, and resurfacing of } 5 \\
\text { kilometers of main roads }\end{array}$ & $\begin{array}{l}\text { Upgrade of Tombo-Gbessia four- } \\
\text { lane road } \\
\text { Works underway in Conakry } \\
\text { (6.775 kilometers), Kindia ( } 2.65 \\
\text { kilometers) et Labé ( } 4.75 \\
\text { kilometers) }\end{array}$ & $\begin{array}{l}\text { Continued } \\
\text { improvement of } \\
\text { Tombo-Gbessia four- } \\
\text { lane road } \\
\text { Works underway in } \\
\text { Conakry (6,775 } \\
\text { kilometers). }\end{array}$ \\
\hline
\end{tabular}

Source: Thematic Group, Monitoring/evaluation of PRS/Ministry of Public Works

Efforts focused on improvement of roads, such as Conakry's TomboGbessia four-lane highway (in progress). These works will speed improve traffic flow and thus ease the circulation of people and freight.

\section{1-3-3. Telecommunications}

The objective is to supply adequate and high-quality post and telecommunication services at competitive prices.

In the area of telecommunications, the main activities in 2005 involved the expansion of SOTELGUI's telephone network. The number of cities served by the GSM network went from 21 to 22, out of a total of 33, for a service coverage rate of 67 percent. Dabola is the most recent city to have been included in SOTELGUI's GSM network. The two other operators, Intercel and Spacetel, cover only the city of Conakry. 
The issuance of a fourth license to InvestCom is expected to improve the country's telephone service coverage. To this end, InvestCom is obligated, within the limits of economic and commercial feasibility, to cover all main urban areas and main road and rail arteries, in terms of territory and population, from the date of effectiveness of the Licensing Agreement as set forth in Article 24 of said Agreement. Under a first phase, the Company will cover all chief towns of prefectures with populations of about 100,000 during the first year following the commercial opening of the network. Under a second phase, the program will cover all chief towns of prefectures with populations under 100,000, within two years of the end of the first phase.

Completion of this program is expected to improve telephone servicerelated indicators and reduce the numerous problems associated with access to telecommunication services.

Table 10: Telecommunications: works completed, 2002-2005

\begin{tabular}{|l|c|c|c|}
\hline \hline \multirow{2}{*}{ Objectives/PRSP indicators } & \multicolumn{3}{|c|}{ Performance } \\
\cline { 2 - 4 } & $2002-2003$ & 2004 & 2005 \\
\hline $\begin{array}{l}\text { Increase in telecom service } \\
\text { density from 0.5 in 2002 to 1 by } \\
\text { 2004, and to 1.5 by 2010 }\end{array}$ & 0.5 & 0.8 & $n . d$. \\
\hline $\begin{array}{l}\text { Total number of subscribers to } \\
\text { SOTELGUI's GSM network }\end{array}$ & 90,000 (2003) & 150,000 & $n . d$. \\
\hline $\begin{array}{l}\text { Number of cities covered by } \\
\text { GSM }\end{array}$ & 18 & 21 & $22^{5}$ \\
\hline \hline
\end{tabular}

Source: National Directorate for Telecommunications

The main challenge is the service quality offered by operators, which leaves much to be desired. Many attempts to call end in failure and the connection is sometimes poor.

This is due to several factors, including poor management, outmoded installations, lack of trained staff, difficulties with power supply, etc.

To improve the situation, efforts must be made to increase the competitiveness of the telephony and telecommunications market. To this end, the Government, by means of Law L/2005/018/AN adopting and

5 Cities covered by the GSM network are: Conakry, Fria, Boké, Boffa, Coyah, Forécariah, Kindia, Mamou, Dalaba, Pita, Labé, Kouroussa, Kankan, Siguiri, Faranah, Kérouane (Banankoro), Kissidougou, Guéckédou, N’Zérékoré, and Dabola. 
promulgating the Law modifying the provisions of Law L/92/016/CTRN of June 2, 1992 on general regulations for telecommunications, has created a regulatory body for the sector of telecommunications, postal service and information and communication technologies. This agency is called the Autonomous Post and Telecommunications Agency (Autonome de Régulation des Postes et Télécommunications, ARPT).

\section{1-4. ECONOMIC PERFORMANCE AND POVERTY REDUCTION}

All economic development experts agree that poverty cannot be reduced without strong and sustainable growth. PRS implementation has suffered from slow growth, despite significant progress made by the Government in 2005 in terms of macroeconomic management.

The growth rate, which was 2.7 percent in 2004, was 3.3 percent in 2005, compared to a PRSP goal of 5 percent. The average annual inflation rate was about 31.4 percent and 29.7 percent year-on-year as of end December 2005, compared to an overall objective of 5 percent. Unemployment has remained stable at 3.0 percent, according to the 2002/2003 EIBEP (see Box 1).

The weakness of economic growth relative to population growth (3.1 percent), the steep increase in the inflation rate, the precariousness of employment, the lack of water and electricity in most cities, and especially in Conakry, are factors aggravating poverty.

This seriously compromises the attainment of poverty reduction objectives set out in the strategic document "Guinea: Vision 2010" (i.e., a 30 percent poverty rate by 2010).

According to estimates, the poverty rate was 53.6 percent in 2005, compared to 49.2 percent in 2002/2003. This situation shows the urgency of measures to be taken under the second PRSP to consolidate the

performance of 2005 so as to achieve a level of growth capable of significantly reducing poverty, especially in rural areas. 
Box 1: Explanatory note on the unemployment rate in Guinea

An unemployed person is defined as any member of the labor force who has not worked during the past 7 days and who has sought employment during the four weeks preceding the survey. The EIBEP provides information on unemployment and job-seeking on the part of the labor force aged 6 years and up and that aged 15 years and up. The analysis, however, is based on unemployment and job-seeking by persons aged 15 and up.

The survey results show that 3.2 percent of the labor force aged 15 and over is unemployed. Unemployment affects men (4.6 percent) more than women (2 percent). It is also primarily an urban phenomenon. Indeed 6.7 percent of the working population residing in cities in the interior and 15 percent of those in Conakry are affected, compared to only 0.4 percent of the labor force living in rural areas.

Relative to the EIBC, the unemployment rate has scarcely changed, since it increased by only 0.1 percent between 1994 and 2002. However, although the unemployment rate for men stayed the same (4.6 percent) over this period, that of women rose from 1.7 percent to 2 percent. Also, although unemployment has decreased slightly in rural areas ( 0.4 percent compared to 0.9 percent), it increased in cities in the interior (from 6.1 percent to 6.7 percent) and especially in Conakry, where it increased by 4.8 percent between 1994 and 2002 (from 10.2 percent to 15 percent.)

In regional terms, after Conakry, where unemployment stands at 15 percent, Lower Guinea, and more specifically the administrative region of Kindia, are areas with high unemployment (3.3 percent in each.)

Source: EIBEP 2002 -2003 DNS/MP/Excerpt from the final report.

\section{1-5. Outlook}

Acceleration of economic growth will once again be a central concern of the Government for the upcoming years. In the immediate future, efforts in 2006 will certainly need to focus on the following objectives:

1) Strengthening of governance and anti-corruption efforts, including strengthening of the national anti-corruption agency ANLC and the promulgation of new laws combating corruption and money laundering.

2) Expansion of the Government's divestiture program;

3) Intensification of the structural reform program;

4) Consolidation and strengthening of macroeconomic policies to ensure sustained macroeconomic stability.

Enterprise reform 
Activities projected for 2006 consist of the sale of enterprise shares, as presented in the following table.

Table 11: Privatization objectives for 2006

\begin{tabular}{|l|l|r|r|r|}
\hline \hline \multicolumn{1}{|c|}{ Enterprise } & \multicolumn{1}{|c|}{ Sector } & \multicolumn{1}{c|}{$\begin{array}{c}\text { Govt. share } \\
\text { (\%) }\end{array}$} & $\begin{array}{c}\text { Share to be } \\
\text { transferred (\%) }\end{array}$ & $\begin{array}{c}\text { Share remaining } \\
\text { (\%) }\end{array}$ \\
\hline BPMG & Banking & 41.66 & 21 & 20 \\
\hline UGAR & Insurance & 18 & 10 & 8 \\
\hline SOMCAG & Petroleum & 34 & 20 & 10 \\
\hline SOPROCHIM & Manufacturing & 33 & 23 & 15 \\
\hline Ciments de Guinée & Manufacturing & 38 & 23 & 15 \\
\hline SOGUILUBE & Manufacturing & 30 & 15 & 10 \\
\hline SALGUIDIA & Manufacturing & 25 & 15 & \\
\hline
\end{tabular}

Source: Privatization Unit/MEF

Revenues generated by the sale of shares in these enterprises are projected to be about GNF 8 billion. Regarding the sale of assets, the operation essentially involves movie theaters ${ }^{6}$ valued together at about GNF 6.3 billion. In connection with measures to promote reinsertion, two outreach workshops are planned to train 200 workers in enterprise creation and microfinance.

Regarding support to sectors with growth potential, the measures envisaged include:

\section{In the area of tourism and handicrafts:}

- Improvement of the institutional framework through development of a Tourism Code designed to provide more incentives to private enterprises investing in the sector;

- Studies concerning the creation of a Pilot Artisans' Center, handicrafts villages, and a bamboo center;

- Strengthening of the technical and professional capacities of actors involved in the sector; and

- Strengthening of partnerships for the construction of tourist encampments.

${ }^{6}$ The movie theaters in question are the Manding (Dinguiraye), Tinkisso (Dabola), Mano (Guéckédou), Soumba (Dubréka), Fatala (Boffa), Simandou (Beyla), and Loffa (Macenta) 
Regarding fisheries and aquaculture, efforts should focus on: (i) finalization of the Letter of Development Policy for Fisheries and Aquaculture (LPDPA) and continuation of the reorganization of the Ministry; (ii) intensification of surveillance efforts and activities combating illegal fishing; (iii) increase in the number of research campaigns, from 2 to 3; (iv) continued development of basic infrastructures and interventions initiated to promote fresh-water fishing and fish farming; (v) completion of the study on the options for stocking ponds and water retention structures with fish; (vi) inventory and rehabilitation of the fleet of fishing canoes; (vii) development and implementation of a program to raise popular awareness of the status of fisheries resources, how to exploit them responsibly, and preserve the aquatic environment; (viii) improving the population's supply of fisheries products and the working conditions of fishermen; (ix) improvement of the sanitary quality of fisheries products in Guinea, the equipment used for the catch (i.e., the boats), transportation and conservation (refrigerated vehicles, cold storage), and processing facilities; (x) development of basic infrastructures and support for artisanal fishing at the fishing port of Boulbinet; and (xi) mobilization of partners for the financing of the fisheries sector.

In the power and water sector, the Government will pursue policies enabling public utility companies to reestablish their financial viability. These measures will improve their operational efficiency, strengthen the regulatory framework, and set a pricing policy conducive to the achievement of the sector's social welfare objectives, while at the same time ensuring the viability of the enterprises in question. With this in mind, all debts owed by public utility companies to the Government were subject of an agreement in September 2005 and a timetable for their settlement was approved. In addition, the Government is envisaging a 20percent power and water rate adjustment for large industrial consumers. An overall pricing policy for the power and water sectors will be approved by January 2007. In this connection, the World Bank is assisting the Government in the reform of the electricity sector, and a bilateral donor is providing assistance in the water sector. 
In the telecommunications sector, measures involve the publication of enforcing decrees and technical orders by the end of December 2006, and the negotiation of operating licenses in accordance with the new regulatory framework aimed at specifying operators' financial, contractual, and technical obligations. In collaboration with the development partners, the Government will also develop an action plan, to be approved in December 2006, for establishing an independent regulatory body as provided for under the new Telecommunications Law.

In the mining sector, reforms will aim to enhance transparency and strengthen the legal framework applicable to private investors. For this purpose, a new standard investment agreement is being developed with the help of the World Bank; it is expected to be approved by decree in September 2006 (and is a structural benchmark for the PRGF). At the same time, the Mining Code will be reviewed to adapt it to the sector's new requirements, including the main elements of the new standard agreement for mining investments.

\section{PART 2: DEVELOPMENT AND ACCESS TO BASIC SOCIAL SERVICES}

The second theme of the PRSP is aimed in general terms at achieving access to an equitable health care system that meets the needs of the population, addresses HIV/AIDS, and covers the expenses of ill persons; education for all; protection and promotion of society's most vulnerable, namely women, children, the elderly, and the handicapped; and access to secure land tenure and decent housing.

\section{2-1. HEALTH SECTOR}

The objective is to improve the health status of the population. To this end, the detailed objectives include prevention and treatment of priority diseases; improved access for the poor to essential health services; and efforts to combat nutritional deficiencies.

Several activities were planned in 2005 in the health sector. The execution rate of these activities is as follows: 
- Regarding rehabilitation of hospitals and upgrading of their technical facilities, the plan was to rehabilitate the hospitals at Gaoual, Koundara, Boké, Yomou, NZérékoré, and Mandiana. Results in this area include the commencement of works, with EU and AfDB financing, in all locations except Gaoual. Rehabilitation of the following is underway: Buruli Ulcer Treatment Center at NZérékoré, Health Centers at Fello Koundoua, Kouratongo (Tougué), and Yimbaya (Ratoma), the teacher housing center at the Rural Health Training Center in Maférinyah, the In-Service Training Center at Donka, and central maternity clinic in Koundara. Eleven (11) conventional $\mathrm{x}$-ray and sonogram machines have also been installed in the hospitals of Dubréka, Kindia, Boké, Télémilé, Mali, Kankan, Siguiri, Labé, Dinguiraye, Ignace Deen, and Donka.

- Regarding improvement of pharmaceutical product availability in health care facilities, the operation of emergency services, increased care capacity of the Hemodialysis Center in Donka, and promotion of hygiene in the two hospitals in Conakry, results indicate that drugs are out of stock due to the currency devaluation and the poor performance of supply chains, inappropriate pricing practices, exorbitant service costs, a lack of professionalism in the CHUs, non-functioning of centers due to a lack of funding, and the breakdown of two generators.

- Regarding efforts to reenergize the professional associations and the General Health Inspectorate to promote adherence to professional ethics, accomplishments include training and outreach workshops held in Conakry for professional associations of pharmacists and physicians, to enable them to internalize the moral and ethical values underlying the medical and paramedical professions. 
- Results in the area of improved mobilization and rational use of funds include: (i) revision of the national pharmaceutical policy with a view to formulating a new drug supply strategy and defining a pricing policy; (ii) signature of a credit agreement on September 29, 2005 with the World Bank for the financing of the health development support program (Appui au Plan National de Développement Sanitaire, APNDS) the goal of which is to reduce maternal and child mortality in 18 prefectures (Koundara, Gaoual, Dinguiraye, Dabola, Kissidougou, Kérouané, Mandiana, Siguiri, Kouroussa, Télimélé, Tougué, Mali, Koubia, Lélouma, Pita, Dalaba, Guéckédou, and Beyla); and (iii) discussion with the World Bank on the development of a health care financing policy, with a view to establishing risk-sharing mechanisms.

- Regarding the assignment of personnel to poor prefectures, 674 recruited employees were assigned to the interior of the country, with priority given to the poor prefectures.

- Efforts to strengthen the national health information system (Systeme National d'Information Sanitaire, SNIS) resulted in the preparation of a statistical yearbook for 2004 and the updating (in progress) of the SNIS with the introduction of new indicators relating to HIV, malaria, and tuberculosis.

Efforts to combat diseases targeted by the EVP have been carried out in recent years. The rate of DTCP3 vaccination coverage improved from 63 percent to 89 percent between 2004 and 2005. In terms of coverage of the prefectures, 30 out of 33 prefectures had a DTCP3 vaccination rate exceeding 80 percent, while the 8 others had a coverage rate below 80 percent.

Regarding VAR and VAA antigen vaccinations, significant improvement has also been noted, with rates rising from 60 percent to 82 percent and from 77 percent to 84 percent, respectively, between 2004 and 2005. At Faranah, a vaccination rate of 87 percent for both antigens was achieved.

This indicates a significant improvement in the quality of vaccination services since 2002, the year in which the VAA was introduced into the routine EVP. 
VAT2+ vaccination coverage also improved, rising from 69 percent in 2004 to 75 percent in 2005. At the regional level, Mamou and Labé had the lowest coverage rates, with 56 percent and 60.4 percent, respectively, relative to the goal of 80 percent that had been set in this area. Great efforts must be made in these two administrative regions to achieve the quantitative goals that have been set. To this end, there must be greater effort to involve communities in strategy formulation, to promote awareness of the importance of the Prefectural Nutrition Centers, and to conduct supervision.

Table 12: Vaccination coverage rates by antigen, $2002-2005$

\begin{tabular}{|l|l|r|r|r|r|}
\hline \hline & Rate of coverage (\%) & 2002 & 2003 & 2004 & 2005 \\
\hline 1 & BCG & 71 & 83 & 71 & - \\
\hline 2 & DTCP3 & 58 & 65 & 63 & 89 \\
\hline 3 & VAR & 61 & 70 & 60 & 82 \\
\hline 4 & VAA & 17 & 33 & 77 & 84 \\
\hline 5 & VAT-2+ & 53 & 56 & 69 & 75 \\
\hline \hline
\end{tabular}

Sources: EPV Directorate/MSP

Overall, it should be emphasized that coverage rates by antigen have improved significantly. This performance is due not only to the commitment of the health district teams, but especially to the support provided by partners in implementing the "Reach Every District" approach; the opening of a Tuberculosis Prevention Center in the town of Matam; the vaccination of 2,257,963 children and 478,495 women against measles and polio; the provision of generators (40 KVA power) to the Regional Directorates of Kindia and N'Zérékoré; the development of a road map for reduction of maternal and neonatal mortality through the organization of a week-long seminar on reproductive health; and the increased number of health centers and integrated health posts in the country.

Over the 2004-2005 period, the number of integrated health posts has increased from 604 to 623 , or by about 3 percent. The number of integrated health centers went from 395 to 399 over the same period, an increase of 4 percent. 
This dynamism in the area of public health was very important in reducing child morality in all categories. Rate of infant, child, and infant/child mortality declines from 98 per thousand to 91 per thousand, from 88 per thousand to 79 per thousand, and from 177 per thousand to 163 per thousand, respectively, between 1999 and 2005. Despite this improvement, these rates are still short of the desired goal of an infant mortality rate of 70 per thousand.

Malnutrition in children under the age of 5 is still not under control, since 26 percent of children suffered from growth delays in 2005, compared to 23 percent in 1999, and 35 percent of children are underweight, against 26 percent in 1999. If measures are not taken to boost awareness and step up efforts to combat poor dietary practices, this situation could have a negative impact on mortality rates.

In the area of HIV/AIDS prevention and treatment, the Government has made numerous efforts in the areas of outreach, screening, care for persons living with HIV (PLHIV), and strengthening of infrastructures.

In 2005, 1,550 women out of 5,002 tested were placed under antiretroviral treatment; 1,295 of them received free ARV treatment. Seven (7) fluoroscopic microscopes and three (3) CD4 counters were purchased. Seven (7) voluntary screening centers and six (6) ambulatory treatment centers were rehabilitated in Matam, Donka, Mamou, Labé, Faranah, and Guéckédou. Four (4) regional blood transfusion centers were renovated in Labé, Kindia, Kankan, and NZérékoré, and 100,000 mosquito nets were distributed.

In addition, 7,800 AIDS orphans, including 1,078 girls, were given care coverage. This measure helps both to mitigate the suffering of PLHIV and to reduce their expenses, thereby helping to reduce poverty and prolong the lives of AIDS sufferers to some degree.

The synergy of interventions has maintained the HIV/AIDS prevalence rate below 5 percent, as set forth in the PRSP objectives. The rates are 1.5 percent nationally, 1.9 percent among women, and 0.9 percent among men. 
Table 13: Seroprevalence and poverty rates by administrative region

\begin{tabular}{|l|c|c|}
\hline \multirow{2}{*}{ Region } & Seroprevalence rate in 2005 (\%) \\
\cline { 2 - 3 } & Men & Women \\
\hline Boké & 0.8 & 1.4 \\
\hline Conakry & 0.6 & 3.4 \\
\hline Faranah & 1.1 & 2.0 \\
\hline Kankan & 1.3 & 1.2 \\
\hline Kindia & 0.9 & 1.0 \\
\hline Labé & 2.1 & 1.7 \\
\hline Mamou & 0.0 & 1.1 \\
\hline NZérékoré & 0.9 & 2.2 \\
\hline Overall & 0.9 & 1.9 \\
\hline \hline
\end{tabular}

Source: Report on initial results of EDS3, 2005

In regional terms, the scourge affects more women (3.4 percent) in the city of Conakry and more men (2.1 percent) in the region of Labé. In Kankan, men and women are affected to the same extent (women: 1.2 percent, men 1.3 percent), and the same is true for the region of Kindia (women: 1.0 percent, men: 0.9 percent).

Despite the low level of seroprevalence in Guinea compared to other countries in the subregion, it should be noted that HIV/AIDS is and will remain a worrisome phenomenon. HIV/AIDS is a factor that aggravates poverty. The two scourges are mutually reinforcing, i.e., poverty is also an aggravating factor in HIV/AIDS.

In view of the problems faced by PLHIV patients, initiatives have been developed to address their care needs in two national and eight regional hospitals, as well as in the Community Medical Center of Matam in Conakry. This care coverage relates essentially to the purchase of equipment, reagents, and drugs, and to employee training, blood supply, and the construction of ambulatory treatment centers.

Although the efforts made by the Health Department to improve health conditions for the population are noteworthy, it should also be noted that the Department has numerous difficulties in fulfilling its mandate, which is to improve the general health status of the population.

These problems include:

\footnotetext{
7 The "zero" value does not mean that the region has no HIV/AIDS cases, but rather that the rate is so low relative to other regions that it can be considered negligible.
} 
- Underequipment of several hospitals and Health Centers, which hampers accurate diagnoses and the provision of high-quality health care services. The equipment lacking includes $\mathrm{x}$-ray machines, reanimation devices, sonograms, etc.;

- Unavailability of drugs due to the fluctuating supply capacities of the pharmaceutical sector and health care establishments, due to the rising cost of drugs, which makes them unaffordable;

- The high cost of health care services in hospital facilities, particularly in the private sector, relative to the financial capacities of most of the population;

- Unfair competition from the informal sector in the supply and sale of pharmaceutical products. The products thus sold are of dubious quality and sometimes hazardous to the health of the population. According to statistics, fraudulent imports accounting for about 45 percent of the pharmaceutical market;

- An inappropriate cost recovery system that fails to cover all of the population's health care requirements;

- The low level of current expenditures by the Government in the health sector, and the low level of recovery of Guinean counterpart funds in the implementation of health projects.

\section{2-2. EDUCATION SECTOR}

In education, the general objectives are to ensure broad access to basic education; to improve access and equity at all educational levels; to improve the quality and efficacy of teaching at all levels; and to enhance non-formal education for the benefit of girls and adults from disadvantages segments of the population.

The results achieved and summarized in Table 14 below show that the gross primary enrollment ratio (GPER) continues to improve: 79 percent in 2005 compared to 77 percent in 2004. The rate for girls also improved, reaching 73 percent in 2005. At this pace, it is highly likely that MDGs in education will be achieved by 2012 . 
Among the administrative regions, N'Zérékoré has a relatively low GPER (66 percent) compared to 127 percent in Conakry. In the interior of the country, the region of Faranah is the only one with a rate (82 percent) that exceeds the national average.

The increased grade repetition rate may be a factor in the rise of these rates. The repetition rate at entry into the $7^{\text {th }}$ year has increased steeply: from 28 percent in 2004, it climbed to about 35 percent in 2005. In Faranah, the rate of repetition at the $7^{\text {th }}$ year entrance exam is still very high (48 percent), and this would explain the gross primary enrollment rate.

As for the girl/boy ratio at the primary level, improvement is noted, with rates rising from 0.76 to 0.79 from 2004 to 2005. At the secondary level, the ratio ranges from 0.47 to 0.49 .

The access rate is significant: 73.3 percent for the country as a whole. In urban areas, it is nearly 89 percent in Conakry and 87 percent in other cities in the interior. In rural areas, the rate is 67.4 percent. The regions of Mamou (50.6 percent), Labé (59.3 percent), and Boké (70 percent) have the lowest access rates. The region of Faranah had a rate of 71 percent, which is obviously below the national average.

An increase in the number of educational infrastructures is also noted. The number of classrooms has been increasing steadily since the implementation of the EFA program began. Classrooms numbered 25,863 in 2004, and there are now 27,018 classrooms for 6,429 schools as of 2005, i.e., 1,115 new classrooms built. Teacher numbers are also on the rise: there are currently 26,897 , of whom 6,540 are women.

Table 14: Indicators and performance in the education sector

\begin{tabular}{|l|c|c|}
\hline \hline PRSP indicators & Performance 2004 & Performance 2005 \\
\hline $\begin{array}{l}\text { Overall gross enrollment ratio of } 100 \\
\% \text { by } 2012\end{array}$ & $77 \%$ \\
\hline Gross enrollment ratio for girls & $70 \%$ & $73 \%$ \\
\hline $\begin{array}{l}\text { Girl/boy ratio at the primary level } \\
\text { (ensure gender equity) }\end{array}$ & 0.76 & 0.79 \\
\hline $\begin{array}{l}\text { Girl/boy ratio at the secondary level } \\
\text { (ensure gender equity) }\end{array}$ & 0.47 & $64.8 \%$ \\
\hline $\begin{array}{l}\text { Overall rate of middle school } \\
\text { admission }\end{array}$ & $72 \%$ & $60.7 \%$ \\
\hline Girls' rate of middle school admission & $69 \%$ & \\
\hline
\end{tabular}

Source: Statistics and Planning Department (SSP)/MEPUEC 
These results highlight the development efforts of the Government and its partners (i.e., local communities, bilateral and multilateral partners, private sector, etc.) in the education sector.

Regarding development funding efforts in the sector with a view to achieving the MDGs and Poverty Reduction Strategy Objectives (PRSO), the Government contribution, in terms of current expenditures, is greater in this sector relative to other social sectors. The Government's current expenditures went from GNF 671.76 billion in 2004 to GNF 1,221.49 billion in 2005, while education expenditures went from 165.46 billion to 197.92 billion. Although current expenditures for education are increasing as a percentage of GDP, they only account for 1.7 percent of such expenditures. This share is low compared to the Sub-Saharan African average, which stands at about 4 percent. This indicates how much more effort must be made to meet the needs of the sector.

Table 15: Current Government expenditures for education, 2002-2005 (GNF billion)

\begin{tabular}{|l|c|c|c|c|c|c|c|c|}
\hline \hline $\begin{array}{l}\text { Level of } \\
\text { expenditure }\end{array}$ & \multicolumn{2}{|c|}{2002} & \multicolumn{2}{c|}{2003} & \multicolumn{2}{c|}{2004} & \multicolumn{2}{c|}{2005} \\
\cline { 2 - 9 } & Amount & $\% G D P$ & Amount & $\% G D P$ & Amount & $\% G D P$ & Amount & $\% G D P$ \\
\hline $\begin{array}{l}\text { Current } \\
\text { expenditure, } \\
\text { education }\end{array}$ & 135.81 & 2.15 & 148.80 & 2.24 & 165.46 & 2.37 & 197.92 & 1.70 \\
\hline $\begin{array}{l}\text { Current } \\
\text { Government } \\
\text { expenditure }\end{array}$ & 588.21 & 9.30 & 613.30 & 9.30 & 671.76 & 9.6 & $1,221.49$ & 10.21 \\
\hline GDP & 6,325 & 100 & $6,644.43$ & 100 & $6,979.98$ & 100 & $11,954.00$ & 100 \\
\hline
\end{tabular}

Source: SSP/MEPUEC and calculations of the authors

Regarding the intrasectoral distribution of the education budget, only the Department of Higher Education received an increase in its allocation in 2005. 
Table 16: Intrasectoral distribution of the education budget (GNF billion)

\begin{tabular}{|l|c|c|c|c|c|c|c|c|}
\hline \multirow{2}{*}{ Year/level } & \multicolumn{2}{|c|}{2002} & \multicolumn{2}{c|}{2003} & \multicolumn{2}{c|}{2004} & \multicolumn{2}{c|}{2005} \\
\cline { 2 - 9 } & Amount & $\%$ & Amount & $\%$ & Amount & $\%$ & Amount & $\%$ \\
\hline Pre-University & 93.0 & 68.5 & 99.9 & 67.1 & 111.4 & 67.3 & 125.16 & 63.2 \\
\hline $\begin{array}{l}\text { Technical and } \\
\text { Vocational }\end{array}$ & 11.8 & 8.7 & 12.4 & 8.3 & 14.0 & 8.4 & 12.29 & 6.2 \\
\hline $\begin{array}{l}\text { Higher } \\
\text { Education }\end{array}$ & 30.9 & 22.8 & 36.5 & 24.5 & 40.1 & 24.2 & 60.49 & 30.6 \\
\hline $\begin{array}{l}\text { Current } \\
\text { expenditure, } \\
\text { education }\end{array}$ & 135.8 & 100 & 148.8 & 100 & 165.5 & 100.0 & 197.92 & 100.0 \\
\hline
\end{tabular}

Source: SSP/MEPUEC and calculations of the authors

In the area of technical education and vocational training, current expenditures declined in 2004 by 8.4 percent, compared to a decline of 6.2 percent in 2005, and account for a share significantly below the 8 percent goal set by the EFA program.

Finally, the share of current expenditures received by higher education improved, rising from 24.2 percent in 2004 to 30.6 percent. This achievement needs to be consolidated through the implementation of policy reforms pertaining to the awarding of scholarships and the optimization of teaching staff resources.

Although expenditures for primary and secondary education have increased in volume by GNF 13.76 billion, they have fallen in relative terms by 4 points compared to 2004. Given the improved transition rate from the primary to the secondary level (from 50 percent to 70 percent over the 2002-2004 period), inadequate expenditures may cause the operating conditions of the establishments to deteriorate.

\subsection{URBAN PLANNING, HOUSING, AND SANITATION}

The objectives of this sector are: sewer installation in residential areas and environmental protection; access for the Guinean population to adequate housing and related services; and reduction of regional disparities and underequipment at the regional level. 
In 2005, activities were undertaken within the framework of the World Bank-supported Third Urban Development Project and Third Water and Sanitation Project (sanitation component).

At the institutional level, the Ministry was reorganized (D/2003/015/PRG/SGG of March 24, 2004) to accommodate the new decentralization options and to involve the private sector and civil society.

Thus, decentralized departments of Urban Planning and Housing have been created at the municipal (commune) level: Technical Departments of Urban Planning, Architecture, and Urban Oversight in Conakry and in the municipalities of Kindia, Kankan, Labé, and N'Zérékoré. The following table details achievements in the sector. 
Table 17: Achievements in the Urban Planning, Housing, and Sanitation sector

\begin{tabular}{|c|c|c|}
\hline $\begin{array}{c}\text { Objectives/PRSP } \\
\text { indicators }\end{array}$ & Performance, 2004 & Performance, 2005 \\
\hline $\begin{array}{l}\text { Development of low- } \\
\text { cost housing sites. }\end{array}$ & $\begin{array}{l}\text { Marketing of parcels in the developed } \\
\text { zone of Sonfonia ( } 150 \text { hectares). } \\
\text { Technical studies for development of a } \\
\text { 200-hectare perimeter in Kéitayah. }\end{array}$ & $\begin{array}{l}\text { Completion of development of } 250 \\
\text { hectares of sites in Sonfonia for a total of } \\
2,500 \text { parcels } \\
\text { Development of a } 200 \text {-hectare perimeter } \\
\text { of sites in Kéitayah for a total of } 1,800 \\
\text { parcels }\end{array}$ \\
\hline $\begin{array}{l}\text { Individual and semi- } \\
\text { collective sanitation } \\
\text { works completed. }\end{array}$ & $\begin{array}{l}\text { Completion of construction and } \\
\text { reception of } 2,535 \text { autonomous } \\
\text { sanitation works in } 520 \text { households, } \\
\text { and of } 60 \text { public latrines in markets, } \\
\text { schools, health centers, bus transport } \\
\text { depots, and public areas of } \\
\text { underequipped neighborhoods in } \\
\text { Conakry. } \\
\text { Completion and reception of the } \\
\text { composting sewage treatment station } \\
\text { at Sonfonia (capacity: } 50 \text { m3/day). } \\
\text { Completion and reception of the natural } \\
\text { sedimentation sewage treatment } \\
\text { station at Yimbaya (capacity: } 100 \\
\text { m3/day). } \\
\text { Completion and reception of } 5 \text { mini } \\
\text { treatment stations (intermittent } \\
\text { filtration, total capacity of } 300 \text { m3/day) } \\
\text { on the sites of large collective } \\
\text { installations at Dixinn (University, } \\
\text { Donka CHU and the three teachers' } \\
\text { housing blocks). }\end{array}$ & $\begin{array}{l}\text { Continuation of sanitation works in } \\
\text { municipalities of Kaloum, Dixinn, Matam, } \\
\text { and Ratoma }\end{array}$ \\
\hline $\begin{array}{l}\text { Number of kilometers } \\
\text { of roads built. }\end{array}$ & $\begin{array}{l}\text { Construction of } 70 \text { kilometers of } \\
\text { paved roads in Conakry; } \\
\text { Construction of } 15 \text { kilometers of } \\
\text { paved roads in Kindia and Dubréka; } \\
\text { Construction of } 4 \text { kilometers of } \\
\text { roads in the towns of Kankan, } \\
\text { Kindia, Labé and Kissidougou. }\end{array}$ & $\begin{array}{l}\text { Rehabilitation and paving of roads: } \\
\text { - } 42.70 \text { kilometers in Conakry and } \\
\text { Dubréka, } 50 \text { percent completed; } \\
\text { - } 19.5 \text { kilometers on the Corniche Sud } \\
\text { and in Kipé, projected to take } 15 \\
\text { months, } 75 \% \text { completed; } \\
\text { - } 13 \text { kilometers in Kindia, projected to } \\
\text { take } 12 \text { months, } 89 \% \text { completed; } \\
\text { - Topographic work and road opening in } \\
\text { the town of Guéckédou, } 90 \% \text { completed; } \\
\text { - Signing of contracts for construction of } \\
\text { offices and housing for police, } \\
\text { gendarmerie, and customs departments. }\end{array}$ \\
\hline
\end{tabular}

Source: Ministry of Urban Planning and Housing. 


\section{2-4. SOCIAL SAFETY NET, PROMOTION OF WOMEN AND CHILDREN}

The objective is to enhance social interventions on behalf of marginalized and socially excluded groups, and to guarantee economic security.

Implementation of the 2004-2010 action plan of the Ministry of Social Welfare, Women's Affairs, and Childhood, which aims to strengthen social welfare interventions and promote equity, yielded the following results in 2005:

In the area of capacity building: updating of the national policy on the promotion of women, and the training of officers of the National Directorate for the Promotion of Women (and its offshoots) in management and public administration, as well as in the management of development projects; training of male and female outreach workers of the CAAF (Centres d'Appui à l'Auto-promotion Féminine) and NAFA Centers in Kaloum, Fria, Labé, and Lélouma in family life and birth control. Their offices were also equipped.

Under the AfDB-financed project to support women's economic activities (Projet d'Appui aux Activités Economiques des Femmes, PAAEF), 19 financial services associations (Associations de Service Financier, ASF) were established in the prefectures of Dabola, Dinguiraye, Faranah, Kankan, Kouroussa, Kérouané, and Mandiana. These associations, by providing 101,793 investment shares, mobilized capital valued in real terms at GNF 101.8 million and obtained credit totaling GNF 331.4 million.

Courses began to be offered in connection with implementation of the three-year Women's Literacy Program, which covers the entire country and targets 300,000 women, in partnership with the Ministry of PreUniversity and Civic Education and with help from the World Bank.

The adoption by the National Assembly of the Women's Rights Protocol of the African Charter on Human Rights, and the dissemination of regional and international instruments for the protection and promotion of equal rights and gender equity, were also important steps forward in the area of women's rights. 
In the health sector in general, and more specifically with regard to HIV/AIDS prevention, a discussion workshop on involving women in efforts to prevent the feminization of the AIDS epidemic and mother-tochild transmission, and in efforts to reduce the incidence of sexually transmitted infections, resulted in the preparation of a national strategy and strategic action plan to combat the feminization of HIV/AIDS. However, women are still faced with many challenges, the most important of which are:

- The troubling extent of illiteracy, the feminization of poverty and the spread of HIV/AIDS among women;

- The persistence of gender inequality, among adults and children, due to certain cultural practices and other sociocultural traditions;

- The lack of acknowledgement of gender issues on the part of decision-makers and communities;

- The small percentage of women in decision-making bodies and positions, at all levels, and the high maternal mortality rate.

In terms of social promotion and protections, considerable progress has been made, essentially in the following areas:

- Draft Law for the Promotion and Protection of the Handicapped;

- Study of the status of the family in Guinea, financed by the United Nations Population Fund (UNPFA), the first draft of which has just been submitted to the Department of Social Welfare, Promotion of Women and Childhood;

- The positive assessment in Lorombo (sub-prefecture of Cisséla) of the $1^{\text {st }}$ round of efforts to bring about the social reinsertion of 97 residents of the Cité de Solidarité;

- 315 case consultations at the National Orthopedic Center and the production of 123 orthopedic devices.

In terms of promotion and protection of children, sexual violence as it relates to juvenile delinquency and HIVAIDS was the focus of initiatives led by the Department. These initiatives resulted in the coordination of activities for a workshop held in Dakar in November 2005. Under the EFA (Education for All) program, 70 Community Outreach Centers (Centres d'Encadrement Communautaires, CEC) are being built in the prefectures of Télimélé, Dabola, Mamou, Kouroussa, and Mandiana.

Finally, regarding social security, the Government examined in April 2005 the report on the actuarial assessment of the National Social Security Fund (Caisse Nationale de Sécurité Sociale, CNSS) with a view to taking steps to: 
- Raise the floor and ceiling salary levels subject to withholding;

- Raise the retirement age;

- Improve registration and coverage of contribution;

- Clarifying the financial relationship between the CNSS and the Government.

In 2005, because of the reform dynamic occurring within it, the CNSS obtained two important working tools that it had previously lacked: Personnel Statutes and a set of Internal Regulations. Fund-raising efforts continued in two areas: consolidation of income and categorization of expenditures. These efforts need to be enhanced through a reorganization of the financial relationship between the Government and the CNSS, i.e., through settlement of the debt owed by the Government. This debt totaled a little over GNF 14 billion as of December 31, 2005.

In carrying out its mandate, the Ministry of Social Welfare and Promotion of Women and Childhood is faced with a number of obstacles to its action program, including:

- Inadequate funding relative to the many challenges in the sector;

- Inadequate human resources at the central and regionalized levels;

- Lack of skills on the part of its personnel;

- Lack of disbursement of subsidies for certain parts of the Department;

- Difficulty in recovering the debt owed to the CNSS by the public treasury.

\section{2-5. OUTLOOK}

In the health sector, in accordance with the orientations defined by the National Program for Health Sector Development (Programme National de Développement de la Santé, PNDS), actions planned for 2006 include:

- Decentralization of health care services for HIV in all administrative regions, including ARV treatment activities, psychosocial support, information dissemination for behavioral change, prevention of mother/child transmission, and support to associations of persons living with HIV;

- Strengthening of efforts to combat malaria and tuberculosis, through IEC activities financed by the Global Fund;

- Pilot experiments aimed at establishing a contractual system between the administration and the private sector, in order to better integrate the overall supply of care and cause rural development communities to develop a feeling of 'ownership' of Health Centers; 
- Finalization and validation of the new pharmaceutical policy, to better regulate this sector and, among other things, combat the illegal market in pharmaceuticals and promote the establishment of private pharmacies in the interior of the country;

- Preparation of a human resource development plan based on recruitment planning, career management, training, and incentives for staff to work in poor areas; and

- Creation of a midwifery track at the Donka paramedical training institute (Institut de formation et de spécialisation des professions paramédicales de Donka) and decentralization of training courses for those seeking the special hospital certification (certificat d'études spécialisées dans les hôpitaux régionaux), in order to encourage them to work in rural areas.

In the area of urban planning, housing, and sanitation, interventions for 2006 will occur within the implementation framework of the following programs:

- National Housing Program (Programme National d'Aménagement et de Développement de l'Habitat) which involves projects and operations to make viable 80,000 hectares of urban sites; the restructuring of 40,000 hectares of sites in old neighborhoods and the production of 1,400,000 decent housing units with least-cost investment;

- National Regional Planning Program (Programme National d'Aménagement du Territoire) which aims to decrease regional disparities; regional underequipment; rural exodus; and underemployment, in order to improve the spatial distribution of investment at the national level;

- The Integrated Development Program for Koba Tatéma - Bamako (Programme d'Aménagement Sous- régional Intégré de Koba Tatéma - Bamako), which is intended to guide regional planning efforts in the direction of subregional economic integration conducive to the development of mutually beneficial exchanges;

- Urban Support Program (Programme d'Appui Technique aux Villes) intended to provide technical assistance to the 33 prefectures in administration and in the management of urban networks and services that derive their main funding from their urban catchment areas; 
- Integrated Development Program for Mining Areas (Programme de Développement Intégré des Régions Minières de la Guinée) which consists of a new approach to rational management of economic and financial potential, with a view to spatially balanced development of mining regions;

- Technical studies for Koloma Plateau (Programme relatif à la réalisation d'études techniques et de travaux d'aménagement du Plateau de Koloma) aimed at promoting more rational urban development in the capital.

In terms of social protections, promotion of women and childhood, the outlook for 2006 includes:

- Revision of sectoral policies of the Ministry of Social Welfare, Promotion of Women and Childhood;

- Monitoring of facilities utilization and of funds used to support targeted population groups;

- Strengthening of the coordination capacities of the Three-Year Women's Literacy Program;

- Continued renovation and equipment of the women's centers (Centres d'Appui à l'Autopromotion Féminine) and vocational centers (Centres de Métiers);

- Preparation of the annual preschool statistical yearbook 2005/2006;

- Continued pedagogical inspection of administrative personnel involved in preschool outreach activities;

- Organization of regional workshops for training and pedagogical monitoring of this personnel;

- Implementation of the results of the qualitative and quantitative study of the status of Guinea's street children and child labor;

- Organization of a subregional meeting on the situation of children in trouble with the law;

- Continuation of evaluation visits to children living in foster institutions, prisons and holding facilities, to improve and update databases on children and women in trouble with the law;

- Continuation of workshops to prepare and implement alternative incarceration options for minors, and organization of a national workshop to harmonize the various prefectural declarations;

- Preparation of a report on the analysis of the status of orphans and vulnerable children, followed by development of a plan of action; and

- Efforts to combat begging by children. 


\section{PART III: GOVERNANCE}

Objectives in the area of governance are the following:

i. Greater decentralization and regionalization of public administration;

ii. Reduction of the impact of corruption on economic and social development;

iii. Greater participation and ownership on the part of the population;

iv. Greater stability and security;

v. Improvement of the country's institutional and human capacities;

vi. Promotion of responsibility and transparency;

vii. Improved knowledge of monitoring and analysis.

\section{3-1. DEMOCRATIC MANAGEMENT AND DECENTRALIZATION}

\section{3-1-1 Democratic management}

The year 2005 was dominated by the preparation and organization of municipal and community elections aimed at replacing municipal and community councils, as set out by law.

Sixteen political parties took part in these elections, which occurred on December 18, 2005, with results announced on December 29. Serious

preparatory work conducted by the Department of Territorial Administration and Decentralization as well as financial and technical assistance from development partners helped make these elections possible.

This upstream work dealt mainly with the revision of the voter rolls to determine the number of registered voters and the compilation of electoral lists. At the same time, a series of consultative "dialogues" between the administration and representatives of the political parties took place on an ongoing basis on the terms and modalities of preparing and organizing elections, in order to ensure a consensus on the part of all those involved, both in Conakry and in the interior of the country.

The introduction of transparent ballot boxes and of a single ballot sheet were important steps forward in terms of political and democratic governance. 
Unfortunately, this dialogue did not produce all the hoped-for results. Responsibility for this is shared between the Ministry of Territory Administration and Decentralization (MATD) and the parties grouped together under the hard-line wing of the opposition constituting the Front for Democratic Change (Front Républicain pour l'Alternance Démocratique, FRAD). These parties were not regular participants in the working sessions.

The creation by decree in November of a national electoral commission (Commission Electorale Nationale Autonome, CENA), responsible for ensuring the fairness of the elections, was the culmination of Government efforts to make these elections an opportunity for transparent and fair consultation. Delays in establishment the CENA's structures unfortunately prevented it from fulfilling its role effectively.

It is also important to mention the significant accomplishment represented by the creation, for the first time and with the help of partners, of a national electoral observatory consisting solely of representatives of civil society. Partners also financed the training of over 40,000 inspectors to oversee the organization and operation of voting offices and the electoral system.

In general, the anomalies observed in the enforcement of laws, particularly by local authorities in connection with the reception and validation of the parties' candidate slates, and the rejection by these same authorities of candidate lists of certain parties in a large number of voting districts, cast doubt on the management of the democratic system and resulted in challenges to election results.

\section{3-1-2. Decentralization}

The strengthening and deepening of the decentralization process went on in 2005, essentially through completion of the review of certain legal texts. The following are particularly noteworthy:

- Finalization of the draft Code of Decentralized Collectivities, which merges 87 legislative and regulatory texts into one document;

- Training, at the Sérédou Training Center, of 48 officials in administration, management of collectivities, and election management techniques;

- Preparation and promulgation of two laws regulating the activities of associations, groups, mutuals, and cooperatives. 
Decentralization was also an important focus of efforts in terms of projects and programs, and particularly for the Village Community Support Program (Programme d'Appui aux Communautés Villageoises, PACV) and the Social Development Program for Upper and Middle Guinea (Programme de Développement Social durable de la Haute et Moyenne Guinée, PDSD/HMG).

These efforts consisted essentially of the following:

- For the PACV:

a) Organization of a workshop to validate studies of tax regimes and on the capitalization and harmonization of tools for the monitoring and planning of CRD management structures;

b) Establishment of the Association of Presidents of CRDs in Guinea within the CRD of Sarékaly (Télimélé prefecture);

c) Information and outreach campaign to inform the population, local elected officials, and officials of decentralized and regionalized departments about the stakes involved in the municipal and community elections.

- For the PDSD/HMG:

a) Training of 3,423 individuals in Upper Guinea and of 3,027 others in Middle Guinea in administrative techniques and practices, purchasing and procurement procedures, and local governance, in connection with efforts to enhance the service provision capacities of decentralized and regionalized departments, and of organizations belonging to civil society;

b) Assistance to collectivities for implementation of the participatory diagnostic, preparation of their development plans, and determination of local investment programs. This same type of assistance was provided to the prefectures for their prefectural development plans;

c) Provision of computers, photocopiers, typewriters, radio communications, office furnishings, miscellaneous supplies, and computer training to the eight prefectures and eight municipalities covered by the project.

\section{3-2. ANTI-CORRUPTION EFFORTS}

The Government's anti-corruption efforts focused mainly on training and outreach to stakeholders to inform them of the devastating impact of corruption on the country's development. 
The National Anti-Corruption Agency (ANLC), despite its scant resources, strove in 2005 to carry out its mandate conscientiously. These efforts included:

- Reception and examination of 16 complaints from citizens. Two of these were resolved to the satisfaction of the parties involved, four were referred to the relevant jurisdictions, and ten require travel within the country;

- Reporting workshops, in July and August 2005 in the administrative regions and in Conakry, concerning the results of the corruption and governance survey;

- IEC activities, including in particular the scheduled distribution of a documentary film and cartoons, and installation of billboards with messages about corruption and governance. The workshop at Faranah, scheduled for July 2006, is the only one remaining. These workshops were the preferred venue for the dissemination of results. A report on all of the regional workshops is available and has been published; and

- Participation in governance-related work organized by public agencies, institutions, and partners.

In addition, after the validation of the 2003 ENCOG, which revealed the extent of the phenomenon in the country (prevalence rate of 36 percent), it is not really possible to assert that corruption has diminished. Therefore, efforts to combat this scourge must continue to focus on:

- Outreach and information on the subject of corruption;

- Promotion of an environment in which people are willing to report instances of corruption, and establishment of measures to protect whistleblowers from reprisals;

- Rigorous oversight of the management of public funds;

- Severe sanctions against offenders, and effective enforcement of those sanctions;

- Establishment of incentives to resist corruption for public administrators at all levels.

In order to ensure the sustainability of the impact of the dissemination of the results of the survey on corruption, and to permit ongoing monitoring of the process of designing a good governance program, the development partners and non-governmental actors recommended that a coordinating body be put in place for the aforementioned program, and that it include representatives of both civil society and the private sector. 
With this in mind, they recommended that the issue's cross-sectoral and multidisciplinary aspects be taken into account in formulating the program. From their standpoint, any design strategy must incorporate a participatory and iterative approach, and non-governmental actors can play a major role. In support of such an approach, an international consultant has already been recruited by the World Bank Institute to assist the process, from the conduct of the survey to the formulation and implementation of an action plan to combat corruption and promote good governance.

Regarding the Extractive Industries Transparency Initiative, the Government and the World Bank have agreed to establish a steering committee on transparency in the extractive industries. But first, and in accordance with the recommendations of the workshop on April 27-28, 2005, a provisional committee consisting of representatives of public administration, republican institutions, civil society, and the private sector was set up and assigned the task of defining the job descriptions, mandates, and composition of the Permanent Steering Committee (Comité Permanent de Pilotage, CPP).

Thus, by Decree 2858/MMG/SGG2005, the Steering Committee was created and its members appointed and given the mandate of compiling available statistics (based on commitments or disbursements), conducting audits, or publishing data on mining revenues in an accessible and comprehensible format.

In this connection, the Permanent Committee carried out the first data gathering and request exercise involving data for 2004 and the first half of 2005. This activity was carried out by two consultants (one local and one expatriate) recruited by the World Bank. In the context of this mission, the terms of reference of the audit were approved by the Permanent Steering Committee. In addition, internal regulations governing the activities of the Steering Committee are currently being approved. To consolidate and raise the visibility of the program, a strategy and action plan are being drawn up and will be validated shortly. 
Concerning anti-corruption efforts, the ANLC, in order to improve management of sectors with growth potential, has continued its in-depth pursuit of investigations initiated in August 2000 by the National AntiCorruption Committee (Comité National de Lutte contre la Corruption, CNLC). These investigations involved the management of fishing licenses and the boarding of vessels. In order to continue these investigations at the request of the Ministry of Justice, the Government has recruited, through ANLC and on the basis of limited competitive bidding, an independent firm to shed light on this matter.

The independent auditing firm, for its part, submitted a draft report in February 2006 on the mission to assess fisheries resources. Despite the administrative difficulties encountered by the firm, and which are being removed by the ANLC as they arise, the mission is continuing in the sector and a final report is anticipated in September 2006.

Since the start-up of its activities, the Permanent Committee has been reorganized into three subcommissions: one for statistics, one for audits, and one for communication and information.

\section{3-3. SECURITY}

The legislative and regulatory texts assign to security departments the responsibility for ensuring the protection of people and their property, assisting the population in the event of disaster (e.g., fire, livestock theft, etc.), and combating crime, drug use, and economic and financial malfeasance.

It is difficult to assert at present that this mandate is being fully carried out and that results are commensurate with expectations. Although they do their best, the security departments are faced with numerous difficulties, including their small staff numbers. At present, the coverage ratio is one police officer for 2,000 residents of Conakry, and 1:6,000 in the interior of the country. Police personnel are also poorly trained, infrastructures are grossly inadequate, and facilities are in an indescribable state of decrepitude and disrepair.

Despite their lack of resources, the security departments were not idle in 2005. Their activities included: 
- In public safety

a) Preparation of a strategy document diagnosing the current security situation and describing actions to be promoted to improve it;

b) Arrest of several armed robbers and malefactors by the BRB, BAC, and CMIS departments;

c) Seizure of 5 metric tons of cannabis, 1,121 kilograms of heroin, and 2.1 kilograms of cocaine. These drugs were incinerated on December 29, 2005;

d) Development of an anti-drug action plan based on a study financed by the European Union;

e) Recruitment of 1,500 police officers.

- In civil security
a) Extinction of 139 fires;
b) 87 body transports;
c) 16 transports of sick individuals;
d) 4 miscellaneous interventions;
e) 3 daily expeditions, on average, during the period of low water pressure in the hydraulic system, to provide safe water to administrations and people in the city of Conakry.

\section{3-4. LEGAL AND JUDICIAL ENVIRONMENT}

Improvement of the legal and judicial environment is a central concern of the PRS. A sound legal and judicial framework is indispensable to development, and therefore critical to poverty reduction. In recognition of this basic concern, several decrees were issued in 2005 concerning the reorganization of the Ministry of Justice, operationalization of the Council of the Magistrature, and the status of clerks of the judicial services. An oversight mission to all jurisdictions in the country occurred in May-June to determine the status of operations in the courts, tribunals, holding facilities and civilian prisons.

In statistical terms, the courts and tribunals rendered 2,260 final verdicts in criminal cases, and 2,129 in civil cases.

However, the justice sector is still faced with difficulties that hamper its operations. These problems include: 
- The inadequacy or absence of legal documents and tools (e.g., codes, decrees, etc.) in the departments and jurisdictions;

- Poor training of magistrates in some areas of jurisprudence;

- Poor working conditions due to inadequate infrastructures and facilities;

- Failure on the part of magistrates to adhere to document processing deadlines, and corruption on the part of some magistrates;

- A high concentration in Conakry of auxiliary judicial personnel (attorneys and bailiffs, etc.), which prevents adequate legal assistance from reaching the interior of the country;

- Interference by administrative authorities in the judicial process, thereby preventing proper law enforcement and the rendering of judicial decisions in accordance with professional standards.

\section{3-5. OUTLOOK}

In the area of decentralization, the following activities are planned for 2006:

a) For the Department of Territorial Administration and Decentralization and the PACV:

- Help the municipalities to prepare their development plans;

- Complete construction of headquarters of certain CRDs and municipalities;

- Encourage and expand decentralized cooperation for the benefit of local collectivities;

- Train officials of decentralized and regionalized departments and elected officials in the new budgetary nomenclature and new fiscal provisions;

- Organize national and regional seminars on the results of, and trends, in, organizations of civil society, in order to gauge the annual impact of their interventions;

- Construct new housing units to enable the Sérédou Training Center to accommodate more trainees and house trainers and permanent staff.

b) For the PDSD/HMG:

- Train officials of regionalized and decentralized structures and civil society in the use of participatory approaches, preparation and management of community microprojects, and mobilization of internal and external funds in Upper and Middle Guinea; 
- Prepare and update local development plans and draw up development plans for the prefectures of Mali and Kouroussa;

- Inform the population and raise awareness, through rural radio broadcasts, of project objectives and PRS implementation strategies.

In the area of anti-corruption efforts, the minimum program defined by the ANLC includes the following activities:

- Establishment of anti-corruption focal points within ministerial departments;

- Reorganization of ANLC to add good governance interventions to its mandate;

- Preparation of an anti-corruption law.

In the area of security, activities will essentially involve:

- Improvement of the institutional framework;

- Recruitment and skill enhancement for police officers (in particular 315 officers intended to supplement the civil security personnel);

- Improvement of facilities and infrastructures at the policy academy in Boffa;

- Construction of 10 urban commissariats in Conakry;

- Renovation of the central commissariats in Conakry and Dubréka;

- Second phase of construction of the DGPN in Coléah. 


\section{PART 4: MONITORING-EVALUATION-COMMUNICATION}

\subsection{POVERTY MONITORING AND ANALYSIS}

The overall objective is to monitor and report on trends in poverty and the impact of poverty reduction policies and programs.

The specific objectives are to: (i) create a Poverty Reduction Statistics System (Système d'Informations Statistiques pour la Réduction de la Pauvreté, SISRP); (ii) improve the body of knowledge concerning HIV/AIDS; (iii) ensure effective participation by all stakeholders in PRS monitoring/evaluation.

In 2005, the following activities were carried out in furtherance of the above-mentioned objectives:

- Continued discussion of the 56 core indicators selected for PRS monitoring and evaluation. To this end, an improved version of the metadata and a report on trends in the 56 indicators were prepared by the SP-SRP with financial and technical assistance from GTZ.

- Training in monitoring/evaluation techniques for about 30 officials of the Thematic Working Group on Growth, with assistance from GTZ (German technical cooperation agency) and the Association of Assessors (Association Guinéenne des Evaluateurs, AGEVAL).

- Preparation of a second progress report on PRS implementation in 2004;

- Continued processing and analysis of EIBEP data, which made it possible to update the database on poverty and to establish a baseline for monitoring and evaluation of PRS performance;

- Finalization of the processing and analysis of results of the baseline survey (ESB) in the zone of the Social Development Project (Projet de Développement Social Durable de la Haute Guinée et de la Moyenne Guinée). The baseline situation in the project zone was assessed on the basis of its results;

- Preparation, processing, and publication of preliminary results of the third Health and Population Survey, on the basis of which health and population data were updated;

- Enhancement of human capacities, in the departments of the Ministry of Planning and the PRS Permanent Secretariat, with regard to poverty analysis techniques using the Macroeconomic Simulation and Poverty Analysis Models (PAMS). 


\subsection{EVALUATION OF PRS IMPLEMENTATION, IMPROVEMENT OF REGIONAL PRS, AND PREPARATION OF THE SECOND PRSP}

In anticipation of a revision of the PRSP, the Government has initiated two important efforts: PRS evaluation and updating of regional PRS. The results of these two operations will be the basis for preparation of the second PRSP.

\subsubsection{Evaluation of implementation}

Under the leadership of four teams of evaluators focusing on four basic themes (governance, health, education, and economic growth), PRS evaluation began in December 2005 with financial support from the European Union and the French Cooperation. It was completed in March 2006.

The ultimate goal of this evaluation is to permit efficient and sustainable implementation of Guinea's poverty reduction strategy, based on improved knowledge of the strengths and weaknesses of the PRSP.

Thus, on the basis of an examination of preliminary results of the thematic reports analyzing and interpreting data on the content of the PRSP and its implementation, it was possible to make the following assessment:

- Inadequacy of funding for further regionalization of public administration;

- Poor functioning of collectivities, despite the existence of legal and regulatory foundations;

- Failure to pay out funding allocations to regionalized structures, despite the announcement made during the PRSP validation visits;

- Diminished operating capacity of the prefectures, resulting in a higher level of indebtedness on the part of the administration;

- Poor planning, along with poor cooperation among the various partners involved, resulting in regional disparities in public investment and unbalanced development at the national level;

- Uneven distribution of health care personnel, resulting in a scarcity of staff at health care facilities and a low level of health service coverage for the population;

- Evacuation of sick patients to referral centers under poor conditions that do not ensure patient safety;

- Improvement of the gross enrollment ratio at the primary and national levels, thereby amply exceeding the goal of 70 percent set forth in the PRSP; 
- Improvement of the GER for girls by 10 points over PRSP goals, which aimed at 63 percent;

- The problem of the level of reading capacity achieved in schools, which is still a core concern of the various policies aimed at improving the educational system, and the resulting decision by authorities to declare 2006 the Year of Reading;

- Inadequate training infrastructures for technical and vocational education;

- High demand for access to higher education;

- Failure to apply the prevailing legal and regulatory procedures in the area of procurement.

\subsubsection{Improvement of regional PRS}

The participatory process of consultation and discussion to improve regional strategies began in August 2005 with the gathering of information and documentation from all administrative regions to serve as the basis for the various workshops on the process.

Two workshops - the process launch workshop and the thematic workshop - have already occurred in the chief towns of the administrative regions, as well as in Conakry. They resulted in: (i) better definition of priority objectives; (ii) clear identification of activities; and (iii) clarification of the roles of the various actors.

\subsubsection{Preparation of the second PRSP}

The second Poverty Reduction Strategy Paper will, like the first, be prepared in a participatory manner, but with greater involvement on the part of civil society. The new approach will also pay great attention to the interfacing of the PRSP-2 with the MDGs. In this connection, the revision of the first PRSP will rely on a number of works either underway or already completed. These include in particular:

a) Results of studies concerning sectoral policies and the funding required to achieve MDGs in Guinea by 2015;

b) The conclusions of the PRS implementation evaluation, which are contained in four (4) thematic reports and one summary report;

c) Six (6) regional Poverty Reduction Strategy Papers, which are being finalized;

d) Contributions from the various Thematic Working Groups" in the form of "Thematic Reports"; and

e) Three (3) PRS implementation progress reports (2003, 2004, 2005). 


\subsection{OUTLOOK}

Although it has been established that progress has occurred in terms of improving the system of monitoring and evaluation of implementation, it must be acknowledged that significant problems remain unresolved. These have to do with: (i) the poor human, logistical, and technical capacities of the statistical departments in the priority sectors; (ii) the poor human, logistical and technical capacities of regional and prefectural bodies charged with PRS monitoring and evaluation; (iii) the lack of standards for assessing poverty reduction projects and programs; (iv) flaws in the organization of a superficial household survey intended to determine trends in well-being; (v) weakness of the human and logistical capacities of the Technical Unit of the PRS Permanent Secretariat ; and (vi) the unreliability of data produced by the national statistical system.

In order to resolve these problems, which are hampering PRS monitoring and evaluation and compromising the analysis of poverty data, the following actions are planned in 2006:

- Development of a national strategy for statistics development (Stratégie Nationale de Développement de la Statistique, SNDS);

- Continuation of evaluation activities;

- preparation of an RGPH;

- Capacity building for decentralized/regionalized departments in the area of monitoring and evaluation;

- Continued fine-tuning of regional strategies. 


\section{CONCLUSION}

The Poverty Reduction Strategy implemented by the Government since 2002 has the overall objective of reducing poverty significantly and sustainably, by increasing incomes and improving the well-being of the population, and particularly of its poorest segments.

To this end, the Government put forth considerable effort in 2005, relative to 2003 and 2004, to improve the macroeconomic situation and to increase access to basic social services. Indeed, the growth rate increased from 2.7 percent in 2004 to 3.3 percent in 2005. This boosted the per capita GDP growth rate, which stands at 0.1 percent, compared to -0.8 in 2004 . Budget execution and resource mobilization have been remarkable: the deficit has shrunk and now stands at -0.8 percent of GDP.

In the social sectors, and particularly in health, village hydraulics, and education, indicators have improved despite financial constraints: the gross enrollment rate rose from 77 percent to 79 percent at the national level; the rate for girls reached 73 percent, surpassing the 2004 level by 3 percentage points. The number of integrated health posts and health centers also increased from 604 to 623 and from 395 to 399 between 2004 and 2005, respectively. The number of water points developed totaled 12,814 in 2005, whereas the access rate in 2002 was already 64.3 percent according to the 2002/2003 EIBEP.

Despite this progress, however, it must be acknowledged that the proportion of the population living below the poverty threshold has significantly increased, rising from 49.2 percent in 2002 to 53.6 percent in 2005. In other terms, the growth achieved has not been sufficient or well distributed enough to benefit the poor.

This situation is due to both endogenous and exogenous factors. Such factors include a low level of economic growth, very high inflation (29.7 percent year-on-year), rising petroleum prices, poor management of public funds, corruption, and lack of accountability, poor interfacing between the budget and the PRSP, etc. 
In view of the foregoing, it is imperative that the Government take bold steps, not only to improve economic governance but also to restore economic growth. This requires concrete anti-corruption measures, an effective monetary policy, better monitoring of public expenditures, etc.

It is only in this way that one can hope to reverse the current poverty trends in Guinea. 
Table 18: Summary of PRS implementation results in Guinea

\begin{tabular}{|c|c|c|c|c|c|c|c|}
\hline \multirow{2}{*}{ Objectives /Indicators } & \multirow{2}{*}{$\begin{array}{l}\text { Baseline } \\
\text { situation }\end{array}$} & \multicolumn{3}{|c|}{ PRSP Objectives } & \multicolumn{3}{|c|}{ Results } \\
\hline & & 2003 & 2004 & 2005 & 2003 & 2004 & 2005 \\
\hline \multicolumn{8}{|l|}{ Reduce incidence of monetary poverty } \\
\hline Incidence of poverty at national level & $62.6 \%(1995)$ & \multicolumn{3}{|c|}{$30 \%(2010)$} & 50.0 & 50.1 & 53.6 \\
\hline Incidence of poverty in rural areas & $82.1 \%(1995)$ & \multicolumn{3}{|c|}{$38 \%(2010)$} & n.d. & n.d. & n.d. \\
\hline \multicolumn{8}{|l|}{ Increase incomes } \\
\hline GDP growth (in \% per annum) & $3.7(1996 / 00)$ & \multicolumn{3}{|c|}{$5.2(2002 / 05)$} & 1.2 & 2.7 & 3.3 \\
\hline GDP growth per capita (\%) & $1.01(1996 / 00)$ & \multicolumn{3}{|c|}{$1.9(2002 / 05)$} & -1.8 & -0.4 & 0.1 \\
\hline Investment rate (\% of GDP) & $16.2(1996 / 00)$ & \multicolumn{3}{|c|}{$18(2002 / 05)$} & 16.1 & 8.9 & 13.2 \\
\hline \multicolumn{8}{|l|}{ Preserve macroeconomic and financial stability } \\
\hline Inflation (\% year-on-year) & $4.3(1996 / 00)$ & \multicolumn{3}{|c|}{$3.5(2005)$} & 14.8 & 27.6 & 29.7 \\
\hline Inflation (average \%) & & & & & 12.2 & 17.5 & 31.1 \\
\hline $\begin{array}{l}\text { Global budget balance } \\
\text { (commitment basis, excl. grants, \% of GDP) }\end{array}$ & $-5.4(2000)$ & \multicolumn{3}{|c|}{$-3,0(2005)$} & -7.9 & -5.9 & -0.8 \\
\hline $\begin{array}{l}\text { Average external current balance } \\
\text { (excl. official transfers, \% of GDP) }\end{array}$ & $-6.0(2000)$ & \multicolumn{3}{|c|}{$-4,0(2005)$} & -4.0 & -5.0 & \\
\hline \multicolumn{8}{|l|}{ Sectoral objectives } \\
\hline \multicolumn{8}{|l|}{ Develop the rural sector } \\
\hline Agricultural growth rate (\% /year) & $5.3(1997-99)$ & \multicolumn{3}{|c|}{$5,0(2002 / 05)$} & 3.9 & 3.5 & 3.3 \\
\hline \multicolumn{8}{|l|}{ Improve educational levels } \\
\hline Gross primary enrollment ratio (\%) & $56.7(1999 / 00)$ & \multicolumn{3}{|c|}{$70(2004 / 05)$} & 74,0 & 77,0 & 79,0 \\
\hline Gross enrollment rate of girls (\%) & $44.3(1999 / 00)$ & \multicolumn{3}{|c|}{$63(2004 / 05)$} & 67,0 & 70,0 & 73,0 \\
\hline Adult literacy rate (\%) & $36(1998 / 99)$ & \multicolumn{3}{|c|}{$45(2007)$} & \multicolumn{3}{|c|}{$38(2003)$} \\
\hline \multicolumn{8}{|l|}{ Improve health status } \\
\hline Gross mortality rate (\%) & $14.2(1999)$ & \multicolumn{3}{|c|}{$12(2005)$} & \multicolumn{3}{|c|}{ n.d. } \\
\hline Infant mortality rate (\%) & $98(1999)$ & \multicolumn{3}{|c|}{$70(2005)$} & \multicolumn{3}{|c|}{$91(2005)$} \\
\hline Maternal mortality rate (per 100,000) & $528(1999)$ & \multicolumn{3}{|c|}{$300(2005)$} & \multicolumn{3}{|c|}{ n.d. } \\
\hline HIV seroprevalence rate (\%) & $2-4(1998)$ & \multicolumn{3}{|c|}{$<5(2004 / 05)$} & & $5(200$ & \\
\hline $\begin{array}{l}\text { Vaccination coverage rate, by antigen (\%) } \\
\text { BCG } \\
\text { DTCP } \\
\text { VHB } \\
\text { VAR } \\
\text { VAA } \\
\text { VAT-2+ }\end{array}$ & $\begin{array}{c}82(2000) \\
43(2000) \\
- \\
40(2000) \\
- \\
38(2000)\end{array}$ & $\begin{array}{l}80 \\
65 \\
20 \\
65 \\
30 \\
75\end{array}$ & $\begin{array}{l}80 \\
75 \\
35 \\
75 \\
40 \\
80\end{array}$ & $\begin{array}{c}71 \\
58 \\
- \\
61 \\
17 \\
53\end{array}$ & $\begin{array}{c}83 \\
65 \\
- \\
70 \\
33 \\
56\end{array}$ & $\begin{array}{l}71 \\
63 \\
67 \\
60 \\
77 \\
69\end{array}$ & $\begin{array}{c}- \\
89 \\
- \\
82 \\
84 \\
75\end{array}$ \\
\hline Increase access to safe water & & & & & & & \\
\hline Population with access to safe water (\%) & 49 (1999) & & $0(200$ & & &, $3(200$ & \\
\hline
\end{tabular}




\begin{tabular}{|c|c|c|c|c|c|c|c|}
\hline \multirow[t]{2}{*}{ Objectives /Indicators } & \multirow{2}{*}{$\begin{array}{l}\text { Baseline } \\
\text { situation }\end{array}$} & \multicolumn{3}{|c|}{ PRSP Objectives } & \multicolumn{3}{|c|}{ Results } \\
\hline & & 2003 & 2004 & 2005 & 2003 & 2004 & 2005 \\
\hline Number of water points built annually & & 800 & 800 & 800 & 658 & 291 & 252 \\
\hline $\begin{array}{l}\text { Sanitation } \\
\text { Construction of individual and public latrines } \\
\text { and wastewater treatment stations }\end{array}$ & & $\begin{array}{l}300 \\
830\end{array}$ & $\begin{array}{l}600 \\
1,170\end{array}$ & $\begin{array}{c}600 \\
1,000\end{array}$ & & & \\
\hline \multicolumn{8}{|l|}{ Improve transportation conditions } \\
\hline Road density $\left(\mathrm{km} / 100 \mathrm{~km}^{2}\right)$ & $2.7(1997)$ & \multicolumn{3}{|c|}{$2.9(2003)$} & \multicolumn{3}{|c|}{$2.8(2003)$} \\
\hline Percentage of network in good condition & $25(1997)$ & \multicolumn{3}{|c|}{36 (2003) } & \multicolumn{3}{|c|}{$30(2003)$} \\
\hline $\begin{array}{l}\text { Rural roads } \\
\text { Dirt road maintenance }(\mathrm{km}) \\
\text { Rehabilitation of dirt roads }(\mathrm{km}) \\
\text { Construction of crossing structures (linear } \\
\text { meters, } \mathrm{Im})\end{array}$ & & $\begin{array}{r}2,150 \\
500 \\
800\end{array}$ & $\begin{array}{c}1,800 \\
500 \\
800\end{array}$ & & $\begin{array}{l}650 \\
457 \\
588\end{array}$ & $\begin{array}{l}689 \\
678\end{array}$ & \\
\hline \multicolumn{8}{|l|}{ Increase access to electricity } \\
\hline Rate of access to electricity (\%) & $16.4(1999)$ & \multicolumn{3}{|c|}{39.4 (2005) } & \multicolumn{3}{|c|}{$18.8(2002)$} \\
\hline
\end{tabular}




\section{BIBLIOGRAPHY}

Banque Mondiale/ Guinée, Diagnostic de la Pauvreté, juin 2005.

International Monetary Fund: Letter of Intent, Memorandum of Economic and Financial Policies and Technical Memorandum of Understanding, May 312005

Groupe de la Banque Africaine de Développement (Mai 2005), Guinée - Document de Stratégie par Pays 2005-2009. Département des opérations par pays Région de l'Ouest.

Ministère de l'Economie et des Finances / Direction Nationale de l'Economie/ Notes de Conjoncture de l'Economie Guinéenne. Division Conjoncture, (décembre 2004 et février 2005).

Ministère de l'Economie et des Finances / Secrétariat Permanent de la Stratégie de Réduction de la Pauvreté (janvier 2002), Document de Stratégie de Réduction de la Pauvreté. Guinée.

Ministère de l'Economie et des Finances / Secrétariat Permanent de la Stratégie de Réduction de la Pauvreté (septembre 2003), Rapport No 001 indicateurs de suivi de la Stratégie de Réduction de la Pauvreté. Groupe thématique suivi évaluation

Ministère de l'Economie et des Finances / Secrétariat Permanent de la Stratégie de Réduction de la Pauvreté (avril 2004), Premier Rapport de mise en œuvre de la Stratégie de Réduction de la Pauvreté. Groupe thématique suivi évaluation

Ministère du Plan / Direction Nationale de la Statistique (avril 2004), Rapport final Enquête sur le Questionnaire des Indicateurs de Base du Bien-être.

Ministère du Plan / Direction Nationale de la Statistique (mai 2004), Enquêtes à Indicateurs Multiples.

Ministère du Plan / Direction Nationale du Plan (juin 2005), Cadrage Macro-économie Annuel 2004, Division Etudes et Stratégies macro-économiques.

Ministère du Plan / Direction Nationale du Plan (novembre 2004), Rapport Economique et Social 2003, Division Etudes et Stratégies macro-économiques.

Ministère du Plan / Direction Nationale de la Statistique (2005), Enquête démographique et de Santé), Division Démographie.

Ministère du Plan / Direction Nationale de la Statistique (1999), Enquête démographique et de Santé), Division Démographie.

Ministère du Plan / Direction Nationale de la Statistique (avril 2004), Rapport final Enquête sur le Questionnaire des Indicateurs de Base du Bien-être.

Ministère de la Santé Publique (février 2005) Discours du Ministre à l'Assemblée Nationale -février 2006. 
Ministère à la Présidence Chargé du Contrôle Economique et Financier / ANLC / Rapport Final de l'Enquête Nationale sur la Corruption et la Gouvernance en Guinée 2003.

Programme des Nations Unies pour le Développement (2004) Impact socio- économique du VIH/SIDA en République de Guinée.

Programme des Nations Unies pour le Développement (2002) Premier Rapport National sur les Objectifs du Millénaire pour le Développement.

Programme des Nations Unies pour le Développement (2005) Deuxième Rapport National sur les Objectifs du Millénaire pour le Développement. 
1. ANNEXES 
Table 19: Execution of expenditures in priority sectors

\begin{tabular}{|l|r|r|r|r|r|}
\hline \multicolumn{1}{|c|}{ GNF billions } & $\begin{array}{c}\text { Completions } \\
\mathbf{2 0 0 2}\end{array}$ & $\begin{array}{c}\text { Completions } \\
\mathbf{2 0 0 3}\end{array}$ & $\begin{array}{c}\text { Completions } \\
\mathbf{2 0 0 4}\end{array}$ & $\begin{array}{c}\text { Completions } \\
\mathbf{2 0 0 5}\end{array}$ & $\begin{array}{c}\mathbf{2 0 0 6} \text { stated } \\
\text { appropriation }\end{array}$ \\
\hline PRIORITY SECGTORS & & & & & \\
\hline JUSTICE & 4.94 & 5.19 & 3.76 & 5.71 & 7.06 \\
\hline AGRICULTURE \& LIVESTOCK & 39.48 & 36.16 & 46.05 & 46.02 & 57.75 \\
\hline FISHERIES \& AQUACULTURE & 3.59 & 3.16 & 3.34 & 5.35 & 10.25 \\
\hline PUBLIC WORKS & 20.18 & 22.98 & 38.52 & 44.46 & 55.96 \\
\hline URBAN PLANNING, HOUSING & 2.51 & 3.52 & 17.27 & 75.70 & 59.55 \\
\hline PUBLIC HEALTH & 49.14 & 39.21 & 26.22 & 44.05 & 66.74 \\
\hline $\begin{array}{l}\text { SOCIAL WELFARE, PROMOTION OF } \\
\text { WOMEN AND CHILDHOOD }\end{array}$ & 3.61 & 3.54 & 3.94 & 5.32 & 9.20 \\
\hline $\begin{array}{l}\text { PRE-UNIVERSITY AND CIVIC } \\
\text { EDUCATION }\end{array}$ & 93.91 & 102.64 & 96.86 & 130.97 & 159.30 \\
\hline $\begin{array}{l}\text { TECHNICAL AND VOCATIONAL } \\
\text { EDUCATION AND TRAINING }\end{array}$ & 12.81 & 13.65 & 10.11 & 12759893 & 15464190 \\
\hline $\begin{array}{l}\text { HIGHER EDUCATION AND SCIENTIFIC } \\
\text { RESEARCH }\end{array}$ & 14.79 & 16.00 & 17.02 & 27.38 & 39.45 \\
\hline HYDRAULICS AND ENERGY & 4.29 & 11.02 & 10.44 & 675921 & 18.42 \\
\hline Common expenditures & 0 & 0 & 0 & 18.24 & 19.43 \\
\hline Total priority expenditures & 249.25 & 257.06 & 273.52 & 416.60 & 518.57 \\
\hline Total expenditures & 1153.00 & 1383.90 & 1464.07 & 1724.95 & 2109.10 \\
\hline Priority expenditures as \% of total expenditures & & $18.6 \%$ & $18.7 \%$ & $\mathbf{2 4 . 2 \%}$ & $\mathbf{2 4 . 6 \%}$ \\
\hline
\end{tabular}


Table 20: PRS Monitoring/Evaluation indicators

\begin{tabular}{|c|c|c|c|c|c|c|}
\hline & Indicators & Unit & 2002 & 2003 & 2004 & 2005 \\
\hline & \multicolumn{6}{|c|}{ ACCERERATION DE LA CROISSANCE } \\
\hline 1 & Debt service, as percentage of exports of goods and services & $\%$ & 16.8 & 20.7 & 20.1 & 18.4 \\
\hline 2 & Proportion of non-mining income within current revenues of Govt. & $\%$ & 81.0 & 86.0 & 82.5 & \\
\hline 3 & Budget deficit, excluding grants (commitment basis) as \% of GDP & $\%$ & 6.2 & 7.9 & 5.9 & 1.4 \\
\hline 4 & Average inflation rate & $\%$ & 3.0 & 12.9 & 17.5 & 31.4 \\
\hline 5 & Inflation, year-on-year & $\%$ & 6.1 & 14.8 & 27.6 & 29.7 \\
\hline 6 & Financing of budget deficit by BCRG (\%) & $\%$ & 61.8 & 40.1 & 27.3 & \\
\hline 7 & Per capita GDP growth & $\%$ & 1.1 & -1.8 & -0.4 & 0.1 \\
\hline 8 & Public investment rate & $\%$ & 3.5 & 3.7 & 5.0 & 5.1 \\
\hline 9 & Private investment rate & $\%$ & 8.8 & 6.3 & 8.2 & 10.8 \\
\hline 10 & National highways in good condition & $\%$ & n.d. & n.d & n.d & \\
\hline 11 & Number of rural roads maintained & $K M$ & 2577 & 650 & 318.2 & \\
\hline 12 & Number of rural roads built & $K M$ & 138. 0 & 457.0 & 678.0 & \\
\hline 13 & Growth rate in agricultural sector & $\%$ & 6.0 & 3.9 & 3.5 & 3.3 \\
\hline 14 & Rate of livestock vaccination (bovine peripneumonia) & $\%$ & 48.2 & & & \\
\hline 15 & Agricultural exports, as share of total exports & $\%$ & 6.4 & 6.8 & 6.9 & \\
\hline 16 & Unemployment rate & $\%$ & 3.2 & n.d & n.d & n.d \\
\hline 17 & Rate of access to electricity & $\%$ & 18.8 & & & \\
\hline
\end{tabular}




\begin{tabular}{|c|c|c|c|c|c|c|}
\hline & Indicators & Unit & 2002 & 2003 & 2004 & 2005 \\
\hline \multicolumn{7}{|c|}{ DEVELOPMENT AND EQUITABLE ACCESS TO BASIC SOCIAL SERVICES } \\
\hline 18 & Households using electricity as main source of lighting (\%) & $\%$ & 18.8 & & & \\
\hline 19 & Gross Primary Enrollment Rate & $\%$ & 72.0 & 74.0 & 77.0 & 79.0 \\
\hline 20 & Gross Secondary Enrollment Rate & & & 27.9 & & \\
\hline 21 & Net Primary Enrollment Rate & $\%$ & 57.0 & 60.0 & 62.0 & 67.0 \\
\hline 22 & Net Secondary Enrollment Rate & $\%$ & & 23.3 & & \\
\hline 23 & Pupil/Teacher ratio, primary level & & 45 & 47 & 46 & 44 \\
\hline 24 & Number of new classrooms built & & 3612 & 836 & 1372 & 1155 \\
\hline 25 & Adult literacy rate & $\%$ & 28.8 & 29.1 & & \\
\hline 26 & Girl/boy ratio at primary level & $\%$ & 0.72 & 0.74 & 0.76 & 0.79 \\
\hline 27 & Girl/boy ratio at secondary level & $\%$ & 0,41 & 0,45 & 0,47 & 0,49 \\
\hline 28 & Literacy rate of women aged $15-19$, relative to men & $\%$ & n.d & n.d & n.d & n.d. \\
\hline 29 & Rate of malaria prevalence & $\%$ & 8,6 & & & n.d. \\
\hline 30 & Infant mortality rate & $\% 0$ & n.d & n.d & n.d & 91 \\
\hline 31 & Mortality rate of children under 5 & $\% 0$ & n.d & n.d & n.d & 163 \\
\hline 32 & Vaccination coverage (BCG) & $\%$ & 71 & 83 & 71 & \\
\hline 33 & Vaccination coverage, DTCP3 & $\%$ & 58 & 65 & 63 & 89 \\
\hline 34 & Vaccination coverage, VAR & $\%$ & 61 & 70 & 60 & 82 \\
\hline 35 & Vaccination coverage, VAA & $\%$ & 17 & 33 & 77 & 84 \\
\hline 36 & Vaccination coverage, VAT-2+ & $\%$ & 53 & 56 & 69 & 75 \\
\hline 37 & Maternal mortality rate (per 100,000$)$ & $\% 000$ & n.d & n.d & n.d & n.d. \\
\hline 38 & Proportion of births attended by qualified health care personnel & $\%$ & & 23,3 & & \\
\hline 39 & Percentage of underweight children under the age of 5 & $\%$ & n.d & n.d & n.d & 35,0 \\
\hline 40 & Number of integrated and operating health centers & & 371 & 391 & 395 & 399 \\
\hline 41 & Number of integrated and operational health posts & & 384 & 515 & 604 & 623 \\
\hline 42 & Rate of HIVIAIDS prevalence & $\%$ & n.d. & n.d. & n.d. & 1,5 \\
\hline 43 & HIVIAIDS prevalence among pregnant women aged $15-24$ & $\%$ & n.d. & n.d. & n.d. & n.d. \\
\hline 44 & Households with access to a source of safe water (\%) & $\%$ & 62,0 & 75,7 & n.d. & n.d. \\
\hline 45 & Number of boreholes dug & & 741 & 646 & 283 & 252 \\
\hline 46 & Number of wells built & & 8 & 12 & 8 & 0 \\
\hline 47 & Number of equipped wells & & 0 & 0 & 0 & 0 \\
\hline
\end{tabular}




\begin{tabular}{|c|c|c|c|c|c|c|}
\hline & Indicators & Unit & 2002 & 2003 & 2004 & 2005 \\
\hline \multicolumn{7}{|c|}{ GOVERNANCE AND STRENGTHENING OF HUMAN AND INSTITUTIONAL CAPACITIES } \\
\hline 48 & Proportion of CRDs lacking savings and loan associations & $\%$ & n.d. & n.d. & n.d. & n.d. \\
\hline 49 & Proportion of national parliamentary seats occupied by women & $\%$ & 19.3 & n.d. & n.d. & n.d. \\
\hline 50 & Number of neighborhood commissariats created & & n.d. & n.d. & n.d. & n.d. \\
\hline 51 & Number of civil society organizations created & & n.d. & n.d. & n.d. & n.d. \\
\hline \multicolumn{7}{|c|}{ PAUVRETE ET DEVELOPPEMENT HUMAIN } \\
\hline 52 & Incidence of monetary poverty (\%) & $\%$ & 49.2 & 50.0 & 50.1 & 53.6 \\
\hline 53 & $\begin{array}{l}\text { Proportion of the population lacking minimum caloric intake (extreme } \\
\text { poverty, in \%) }\end{array}$ & $\%$ & 8.1 & & & \\
\hline 54 & Proportion of the population living on less than USD1 per day (PPA) & $\%$ & n.d. & n.d. & n.d. & n.d. \\
\hline 55 & Depth of poverty & $\%$ & 17.2 & 17.6 & 17.5 & 19.3 \\
\hline 56 & GINI index & & 0.40 & n.d. & n.d. & n.d. \\
\hline
\end{tabular}

